\title{
Low-level summertime isoprene observed at a forested mountaintop site in southern China: implications for strong regional atmospheric oxidative capacity
}

\author{
Daocheng Gong ${ }^{1}$, Hao Wang ${ }^{1,2}$, Shenyang Zhang ${ }^{1}$, Yu Wang ${ }^{3}$, Shaw Chen Liu ${ }^{1}$, Hai Guo ${ }^{3}$, Min Shao ${ }^{1}$, \\ Congrong $\mathrm{He}^{2,4}$, Duohong Chen ${ }^{5}$, Lingyan $\mathrm{He}^{6}$, Lei Zhou ${ }^{1}$, Lidia Morawska ${ }^{2,4}$, Yuanhang Zhang ${ }^{7}$, and \\ Boguang Wang ${ }^{1,2}$ \\ ${ }^{1}$ Institute for Environmental and Climate Research, Jinan University, Guangzhou 511443, China \\ ${ }^{2}$ JNU-QUT Joint Laboratory for Air Quality Science and Management, Jinan University, Guangzhou 511443, China \\ ${ }^{3}$ Air Quality Studies, Department of Civil and Environmental Engineering, The Hong Kong Polytechnic University, \\ Hung Hom, Hong Kong \\ ${ }^{4}$ International Laboratory for Air Quality and Health, Queensland University of Technology, P.O. Box 2434, \\ Brisbane, Queensland 4001, Australia \\ ${ }^{5}$ State Environmental Protection Key Laboratory of Regional Air Quality Monitoring, Guangdong Environmental Monitoring \\ Center, Guangzhou 510308, China \\ ${ }^{6}$ Key Laboratory for Urban Habitat Environmental Science and Technology, School of Environment and Energy, \\ Peking University Shenzhen Graduate School, Shenzhen 518055, China \\ ${ }^{7}$ State Key Joint Laboratory of Environmental Simulation and Pollution Control, College of Environmental Sciences and \\ Engineering, Peking University, Beijing 100871, China
}

Correspondence: Boguang Wang (tbongue@jnu.edu.cn)

Received: 29 March 2018 - Discussion started: 16 May 2018

Revised: 11 September 2018 - Accepted: 15 September 2018 - Published: 9 October 2018

\begin{abstract}
To investigate the atmospheric oxidative capacity (AOC) in forested high mountain areas adjacent to the photochemistry-active Pearl River Delta (PRD) region in southern China, one-month online observations of isoprene and its oxidation products methyl vinyl ketone (MVK) and methacrolein (MACR) were conducted at a national background station in Nanling Mountains in summer 2016. The results showed that the observed daytime isoprene levels $(377 \pm 46 \mathrm{pptv})$ were significantly lower in comparison with other forest sites within and outside China, although the sampling site was surrounded with subtropical evergreen broad-leaved trees which are strong isoprene emitters. Also, high daytime (MVK + MACR) / isoprene ratios $(1.9 \pm 0.5)$ were observed. Based on the observations, we hypothesized that the lower isoprene levels in the study forest might be attributable to a strong $\mathrm{AOC}$ in relation to the elevated regional complex air pollution. In further data analyses, high site-level concentrations of daytime $\mathrm{OH}$ $\left(7.3 \pm 0.5 \times 10^{6}\right.$ molecules $\left.\mathrm{cm}^{-3}\right)$ and nighttime $\mathrm{NO}_{3}$ radicals
\end{abstract}

$\left(6.0 \pm 0.5 \times 10^{8}\right.$ molecules $\left.\mathrm{cm}^{-3}\right)$ were estimated by using a photochemical box model incorporating the master chemical mechanism (PBM-MCM), and high regional mixing ratios of $\mathrm{OH}\left(19.7 \pm 2.3 \times 10^{6}\right.$ molecules $\left.\mathrm{cm}^{-3}\right)$ during 09:0015:00 LT were also obtained by applying a parameterization method with measured aromatic hydrocarbons. And besides, high initial mixing ratios $(1213 \pm 108 \mathrm{pptv})$ and short atmospheric reaction time $(0.27 \mathrm{~h})$ of isoprene during the day were derived by a sequential reaction approach. All these indicate that isoprene was rapidly and highly oxidized in this forest, which supports our hypothesis. The study suggests that the complex air pollution in the PRD may have significantly elevated the background $\mathrm{AOC}$ of the adjacent forests, and probably affects the regional air quality and ecological environment in the long term. The feedback of forest ecosystems to the increasing AOC in southern China warrants further studies. 


\section{Introduction}

Isoprene (2-methyl-1,3-butadiene) is the most abundant nonmethane volatile organic compound (NMVOC) in the atmosphere (Guenther et al., 2012). The high abundance and reactive chemistry of isoprene affect the oxidative capacity of the troposphere and contribute to the formation of ozone $\left(\mathrm{O}_{3}\right)$ and secondary organic aerosols (Claeys et al., 2004; Hewitt et al., 2011). The biogenic sources from terrestrial vegetation contribute more than $90 \%$ of atmospheric isoprene, with the largest contribution from forests (Guenther et al., 2006).

Isoprene emissions from forests have been extensively studied over the past decades (Sharkey and Yeh, 2003). More recent works have expanded the focus from emissions (Gu et al., 2017) to impacts of isoprene on regional forest chemistry (Taraborrelli et al., 2012; Liu et al., 2016, 2018). These studies have greatly improved our understanding of the oxidation process of isoprene, revealed current uncertainties associated with isoprene emission rates and degradation schemes, and highlighted the biogenic-anthropogenic interactions in moderately polluted forests (Rohrer et al., 2014). Recent studies in pristine Amazon forests have reported the disturbance of anthropogenic influence to the oxidation of isoprene and the amplification of atmospheric oxidative capacity (AOC) (Liu et al., 2016, 2018). However, studies on this kind of disturbance and amplification in certain polluted isoprene-rich environments, such as the forests surrounding megacities, remain scarce (Hofzumahaus et al., 2009).

Isoprene can be rapidly removed by oxidation of hydroxyl radicals $(\mathrm{OH})$, once being released into the troposphere during the day. The oxidation is usually initiated by an additional reaction of an $\mathrm{OH}$ across the double bond and followed by a fast reaction with molecular oxygen. A population of hydroxyl-substituted isoprene peroxyl radicals (ISOPOO) is thereby produced (Orlando and Tyndall, 2012). The subsequent chemistry of the ISOPOO proceeds along several competing pathways (Jenkin et al., 2015). In a real ambient environment, the major competing reaction pathways include both NO- and $\mathrm{HO}_{2}$-channels, which dominate in polluted and pristine atmospheres, respectively (Paulot et al., 2009; $\mathrm{Su}$ et al., 2016). The relative importance of the two pathways varies with $\mathrm{NO}_{x}\left(\mathrm{NO}_{x}=\mathrm{NO}+\mathrm{NO}_{2}\right)$ mixing ratios. Ambient measurements in pristine Amazon forests demonstrated that high $\mathrm{OH}$ concentrations often occur under high-isoprene and low- $\mathrm{NO}_{x}(<1 \mathrm{ppbv})$ conditions where $\mathrm{OH}$ regeneration contributes greatly to the oxidative capacity of the atmosphere (Lelieveld et al., 2008; Fuchs et al., 2013; Rohrer et al., 2014). Several recent studies have shown that small increases of $\mathrm{NO}_{x}$ concentration above the background level can lead to a large change in the oxidative capacity and chemistry of the forest atmosphere (Liu et al., 2016, 2018; Su et al., 2016; Santos et al., 2018). In addition, the high OH-recycling efficiency is not unique to pristine forests; an important but different $\mathrm{OH}-$ recycling mechanism has been discovered in an isoprene-emitting forest suffering from heavy air pollution
(Hofzumahaus et al., 2009). Thus, it is vital to understand the isoprene photochemistry under moderately polluted forest atmospheric conditions with high isoprene emissions and a broad range of $\mathrm{NO}_{x}$ concentrations.

In moderately polluted environments, e.g. forests surrounding urban areas, nitrate radicals $\left(\mathrm{NO}_{3}\right)$, which form mainly from the oxidation of $\mathrm{NO}_{2}$ by $\mathrm{O}_{3}$, are the dominant oxidant of isoprene at night when photochemical production of $\mathrm{OH}$ has diminished ( $\mathrm{Ng}$ et al., 2017). The nitrate radicals can be abundant at night and short-lived during the day due to their rapid photolysis in sunlight and its reaction with NO (Wayne et al., 1991). While nighttime isoprene emissions are negligible, isoprene emitted in the late afternoon can accumulate in the nighttime atmosphere. Organic nitrates produced from the isoprene $+\mathrm{NO}_{3}$ reactions will be abundant enough to affect the nighttime radical chemistry and to persist into daytime where they may serve as $\mathrm{NO}_{x}$ reservoirs (Perring et al., 2009). Therefore, isoprene $\mathrm{NO}_{3}$ chemistry is important for understanding the nighttime oxidative capacity in moderately polluted forest atmospheres.

Methyl vinyl ketone (MVK) and methacrolein (MACR) are key intermediates generated from isoprene oxidation with $\mathrm{OH}$ and $\mathrm{NO}_{3}$ (Sprengnether et al., 2002; Perring et al., 2009). The sum of MVK and MACR accounts for about $80 \%$ of the carbon in the initial stage of isoprene oxidation in the atmosphere (Jenkin et al., 2015). Field measurements of MVK and MACR have been widely conducted during the past decades to explore the oxidation mechanisms of isoprene in forested environments (Stroud et al., 2001; Apel et al., 2002; Kuhn et al., 2007; Kalogridis et al., 2014; Liu et al., 2016, 2018; Santos et al., 2018). Few studies, however, have been performed at high-altitude mountain sites to investigate the influence of anthropogenic emissions to the isoprene oxidation and to evaluate the regional AOC (Reissell and Arey, 2001; Dreyfus et al., 2002; Guo et al., 2012). In this study, to deepen the scientific understanding of the isoprene oxidation and the background $\mathrm{AOC}$ on a regional scale, measurements of isoprene and its oxidation products were performed in Nanling mountains during the summer of 2016. To our knowledge, this was the first study of isoprene observation at a remote and forested mountaintop site in southern China.

This paper is structured as follows. Firstly, an overview of the meteorological and chemical conditions is given. Second, the measured concentrations and diurnal variations of isoprene and its oxidation products are presented. Then the estimated concentrations of daytime $\mathrm{OH}$ and nighttime $\mathrm{NO}_{3}$ are presented and discussed in detail. And furthermore, the initial mixing ratios and atmospheric reaction time of isoprene were estimated. Finally, concluding remarks including a synthesis of current findings and some implications are presented. In this study, unexpected low isoprene levels and high (MVK + MACR) / isoprene ratios were observed. The subsequent theoretical calculations confirmed that the rapid and high isoprene oxidation might be attributable to a strong 
AOC in relation to the elevated regional complex air pollution in southern China.

\section{Methods}

\subsection{Site description}

The observations were conducted at a national background station in the Nanling Mountains that adjacent to the photochemistry-active Pearl River Delta (PRD) region in southern China. The PRD has become one of the most airpolluted areas in China, which happened along with rapid economic growth and urbanization over the past few decades (Chan and Yao, 2008). A number of studies have pointed to worsening photochemical pollution in this region (Wang et al., 2009; Zheng et al., 2010; Li et al., 2018). Highest ever reported concentrations of $\mathrm{OH}$ have been observed in the PRD by recent studies (Hofzumahaus et al., 2009; Lu et al., 2012, 2014), indicating the strong AOC in this region. Limited studies of $\mathrm{NO}_{3}$ oxidation chemistry have also confirmed the considerable potential of $\mathrm{NO}_{3}$ for the strong nighttime and even daytime atmospheric oxidative capacities in the PRD (Xue et al., 2016; Brown et al., 2016; Li et al., 2018). Ground-level $\mathrm{O}_{3}$, another indicator of the regional AOC, was also high in the PRD, with hourly mixing ratios of up to $220 \mathrm{ppbv}$ (T. Wang et al., 2017). Furthermore, $\mathrm{O}_{3}$ in this region was observed to increase at a rate of 0.27 to 0.86 ppbv year $^{-1}$ (Wang et al., 2009; Y. Wang et al., 2017; Xue et al., 2014a). All these studies consistently demonstrate strong and enhancing AOC in the PRD.

To the north of the PRD lies the Nanling Mountains, an important geographic boundary in southern China separating the temperate areas in the north from subtropical regions on the south-east coast. The mountain range straddles more than $1000 \mathrm{~km}$ from west to east across the borders of four provinces (i.e. Guangxi, Hunan, Guangdong and Jiangxi). Influenced by the East Asian monsoons, the area is the key pathway for the long-range transport of air pollutants between southern and central-eastern China, making it a suitable location to monitor the regional background air quality. With a forest area of 5.36 million hectares, the Nanling Mountains holds the best preserved and the most representative subtropical forest in the regions of the same latitude in the world. The trees and shrubs in this region are mainly composed of subtropical evergreen broad-leaved and moso bamboo forests (SFAPRC, 2014), both of which are well known to be strong isoprene emitters (Bai et al., 2016, 2017). Therefore, the Nanling Mountains area is an ideal location for exploring anthropogenic-biogenic interactions because of its high natural emissions and its proximity to anthropogenic pollution sources. So far, however, no isoprene measurements have been conducted in this important area.

The sampling site $\left(24^{\circ} 41^{\prime} 6^{\prime \prime} \mathrm{N}, 112^{\circ} 53^{\prime} 56^{\prime \prime} \mathrm{E}\right.$, $1690 \mathrm{~m}$ a.s.l.) located at the summit of Mt. Tian Jing in

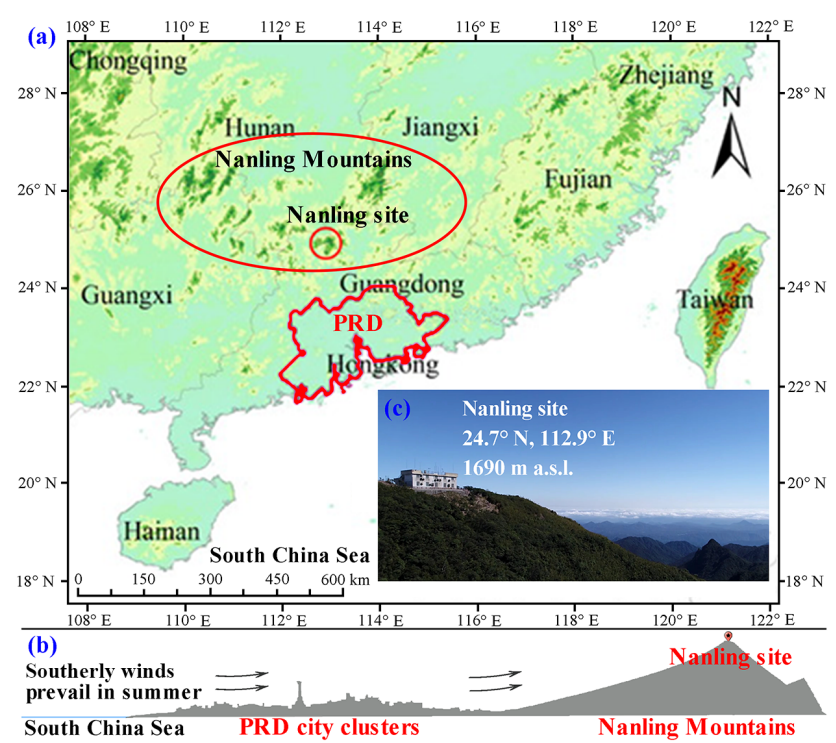

Figure 1. (a) Map showing the location of the Nanling site at the summit of Mt. Tian Jing in southern Nanling Mountains; (b) also shown is the sketch of the cross-section of the PRD and Nanling Mountains; (c) aerial photo of the Nanling site. The base map in (a) and (b) are reproduced from $\mathrm{Wu}$ et al. $(2016,2013)$, respectively.

the southern slope of the Nanling Mountains (Fig. 1) is $\sim 15 \mathrm{~m}$ above the forest canopy. The site is far from urban and industrial areas and free of any emissions from local anthropogenic activities. Mt. Tian Jing is the highest mountain within a radius of $24 \mathrm{~km}$, with no obstacles around. To the south are the city clusters of the PRD $(178 \mathrm{~km}$ north of the metropolitan Guangzhou). During the East Asian summer monsoon seasons (June to September), polluted air from the PRD or even Southeast Asia may reach the sampling site. As the Nanling site is a high-altitude mountaintop site in a remote region, and highly representative of the upper planetary boundary layer (PBL) or lower free troposphere (FT) in southern China, measurements of surface isoprene and other species can well represent a large-scale situation.

\subsection{Measurement techniques}

\subsubsection{Sampling and analysis of VOCs}

The continuous sampling and analysis of ambient VOCs at the Nanling site were conducted automatically by a state-ofthe-art online cryogen-free GC-MS (gas chromatographymass spectrometry) system with a time resolution of $1 \mathrm{~h}$ in summer 2016 (i.e. 15 July-17 August). The VOC measurement instruments were deployed inside a two-storey building. The inlet of the sampling tube was located $1.5 \mathrm{~m}$ above the rooftop of the building. Ambient air samples were drawn through a $5 \mathrm{~m}$ perfluoroalkoxy tube (OD 1/4 inch). The system consisted of a cryogen-free trap pre-concentration device (TH-PKU 300B, Wuhan Tianhong Instrument Co., 
Ltd., China) and a gas chromatography-mass spectrometry (7820A GC, 5977E MSD, Agilent Technologies Inc., USA). The details of this system are described elsewhere (Wang et al., 2014). Briefly, the ambient air was sampled and pumped into an electronic refrigeration and pre-concentration system at a flow rate of $60 \mathrm{~mL} \mathrm{~min}^{-1}$ for the second $5 \mathrm{~min}$ of each hour. In order to prevent particulate matters from entering into the sampling system, a Teflon filter $(0.25 \mu \mathrm{m}$ pore size, $47 \mathrm{~mm}$ OD, MilliporeSigma, USA) was placed in front of the sample inlet. Moisture and $\mathrm{CO}_{2}$ were removed before VOC analysis by a water management trap and a soda asbestos tube, respectively. VOCs were separated on a semi-polar column $(\mathrm{DB}-624,60 \mathrm{~m} \times 0.25 \mathrm{~mm}$ ID $\times 1.4 \mu \mathrm{m}$, Agilent Technologies Inc., USA) and then quantified using a quadrupole MS detector with a full-scan mode. The GC oven temperature was programmed initially at $38^{\circ} \mathrm{C}$ for $3.5 \mathrm{~min}$, increasing to $180^{\circ} \mathrm{C}$ at a rate of $6^{\circ} \mathrm{C} \mathrm{min}^{-1}$ and holding for $15 \mathrm{~min}$. The entire process took about $43 \mathrm{~min}$.

Rigorous QA (quality assurance) and QC (quality control) procedures were performed through the entire measurement period. To assess the wall loss of VOCs when air was passing through the sampling tube, canister sampling at the sampling tube inlet was conducted simultaneously with the online measurements, and samples were analysed using the offline mode of the instrument at night of the same day. 24 offline samples were collected by canisters during the campaign. The slope and correlation coefficient $\left(R^{2}\right)$ of a plot between offline samples and online measurements for isoprene, MVK and MACR is $0.98-1.01$ and $>0.99$, respectively. Calibration curves were established for each individual species at seven different concentrations ranging from 10 to 2000 pptv before sample analysis. The GC-MS system was also calibrated using four internal standards (Bromochloromethane, 1,4-Difluorobenzene, Chlorobenzene-d5 and 4-Bromofluorobenzene). A mixture of 57 non-methane hydrocarbons and a mixture of oxygenated VOCs (Linde Electronics and Specialty Gases, USA) were used to make the standard curves for calibration. $R^{2}$ values of calibration curves were $>0.99$ for all species. Daily calibrations were performed with $\pm 10 \%$ variations with reference to the calibration curve results. The method detection limit (MDL) for isoprene, MVK and MACR quantified with this system was 4, 15 and 10 pptv, respectively.

\subsubsection{Measurements of trace gases and meteorological parameters}

Ozone $\left(\mathrm{O}_{3}\right)$ was measured using a commercial UV photometric instrument (Model 49i, Thermo Fischer Scientific Inc., USA), which has a detection limit of 0.5 ppbv. Oxides of nitrogen $\left(\mathrm{NO}-\mathrm{NO}_{2}-\mathrm{NO}_{x}\right)$ were measured at 1 min resolution using a chemiluminescence analyser (Model 42i-TL, Thermo Fischer Scientific Inc., USA), which has a detection limit of 0.05 ppbv. $\mathrm{NO}_{2}$ is converted to $\mathrm{NO}$ by a heated molybdenum converter before it can be measured by the chemiluminescence detection of NO. This method may cause an overestimation of $\mathrm{NO}_{2}$ because the measured $\mathrm{NO}_{2}$ probably includes some oxidized reactive nitrogen converted by the heated molybdenum ( $\mathrm{Xu}$ et al., 2013). Thus, the $\mathrm{NO}_{2}$ concentrations given below are considered as the upper limits of their actual values. Sulfur dioxide $\left(\mathrm{SO}_{2}\right)$ was measured by pulsed UV fluorescence (Model 43i-TLE, Thermo Fischer Scientific Inc., USA) with a detection limit of 0.05 ppbv. Carbon monoxide (CO) was monitored using a gas filter correlation infrared absorption trace level analyser (Model 48i-TLE, Thermo Fischer Scientific Inc., USA). All instruments were calibrated weekly by using a multi-gas calibrator (Model 146i, Thermo Fischer Scientific Inc., USA) throughout the study. The NIST-traceable (National Institute of Standards and Technology, USA) standard was applied to calibrate the $\mathrm{O}_{3}$ analyser. For the calibration of the $\mathrm{NO}_{x}, \mathrm{SO}_{2}$ and $\mathrm{CO}$ analysers, standard gases provided by the NRCCRM (National Research Center for Certified Reference Materials, China) were applied. Zero and span checks of all analysers were performed every 2 days. In addition to the above chemical measurements, key meteorological parameters were monitored by an integrated sensor suite (WXT520, Vaisala, Inc., Finland) including temperature, relative humidity, wind speed, wind direction and precipitation.

\subsection{Estimation of site-level $\mathrm{OH}$ and $\mathrm{NO}_{3}$ concentrations by photochemical box model}

Since the $\mathrm{OH}$ and $\mathrm{NO}_{3}$ concentrations were not measured in this campaign, they were estimated by using a photochemical box model incorporating the master chemical mechanism (PBM-MCM). MCM (v3.2) has a good performance on calculating free radicals and intermediate products (Jenkin et al., 1997, 2003; Saunders et al., 2003), as it adopts a nearexplicit mechanism, involving 5900 chemical species and around 16500 reactions. In this study, the observed hourly data of air pollutants $\left(\mathrm{O}_{3}, \mathrm{NO}, \mathrm{NO}_{2}, \mathrm{CO}, \mathrm{SO}_{2}\right.$ and VOCs) and meteorological parameters (temperature and relative humidity) for the sampling period were input into the model for simulations. More detailed descriptions of the PBM-MCM are provided in Ling et al. (2014), Guo et al. (2013) and Cheng et al. (2010). It is noteworthy that the vertical and horizontal transport and the heterogeneous process of $\mathrm{N}_{2} \mathrm{O}_{5}$ were not considered in the PBM-MCM. Sensitivity analyses were conducted for the model by varying the mixing ratios of $\mathrm{NO}_{2}$ and $\mathrm{HONO}$.

\subsection{Estimation of regional mixing ratios of daytime $\mathrm{OH}$}

Few previous studies have suggested that MCM may not work well for reproducing the $\mathrm{OH}$ concentrations in pristine forest environments (Kim et al., 2015). In addition, the $\mathrm{OH}$ mixing ratios modelled by the PBM-MCM can only represent the levels at the site. To provide a complement to the PBM-MCM, a widely used parameterization method 


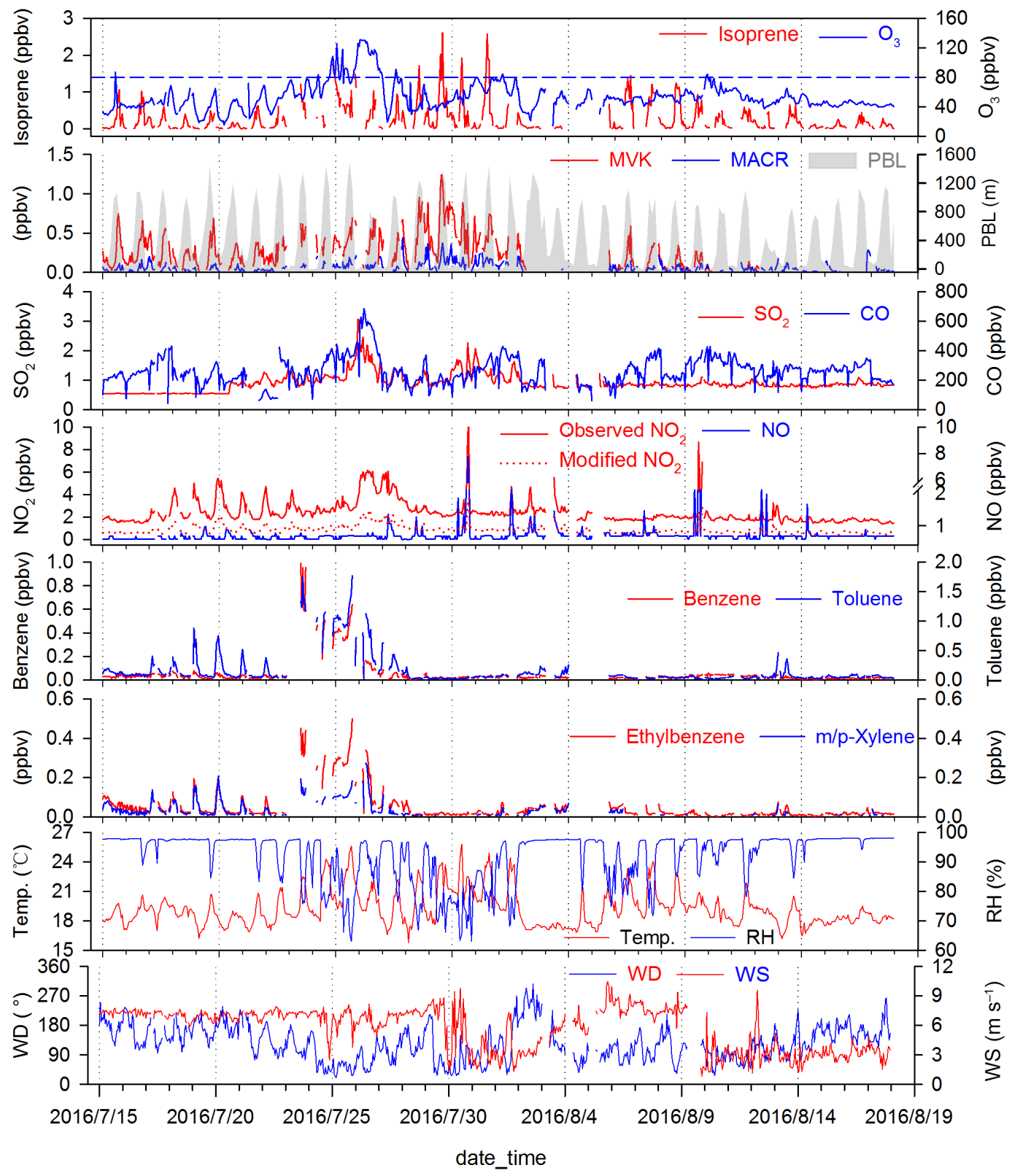

Figure 2. Time series (1 h data) of trace gases, meteorological parameters and the planetary boundary layer (PBL) height (PBL data provided by Real-time Environmental Applications and Display sYstem, https://ready.arl.noaa.gov/READYamet.php, last access: 14 July 2018) during 15 July-17 August 2016 at the Nanling site. Modified $\mathrm{NO}_{2}$ defined here as the product of modification factor (Fig. S1) and observed $\mathrm{NO}_{2}$. Blue dashed lines are Grade I of the ambient air quality standard in China for $\mathrm{O}_{3}$ ( $80 \mathrm{ppbv}$ ). Temperature, relative humidity, wind speed and wind direction are referred to as Temp., RH, WS and WD, respectively.

using measured aromatic hydrocarbons (i.e. BTEX, benzene, toluene, ethylbenzene and $m, p$-xylene) was applied to estimate the regional mixing ratios of daytime $\mathrm{OH}$ (Shiu et al., 2007). The ratios of any two aromatics having the same emission sources but different photochemical reactivities can be used to measure photochemical oxidation (Parrish et al., 2007). This approach is based on three assumptions: (1) BTEX are removed from the atmosphere following pseudo-first-order kinetic; (2) no fresh BTEX are emitted to the air mass in the transport; and (3) the effects of horizontal and vertical mixing are similar for each compound. More details about the parameterization method are given in Sect. S1 in the Supplement. 


\subsection{Calculation of initial isoprene}

To check out the magnitude of isoprene oxidation, the initial isoprene was calculated using a sequential reaction approach based on the isoprene's oxidation mechanism and an empirical relationship between isoprene and its first-stage oxidation products (i.e. MVK and MACR) (Wolfe et al., 2016). This simplified parameterization method is based on four assumptions: (1) no fresh emissions of isoprene are introduced, and isoprene emissions are constant during the process; (2) there were no additional sources of MVK and MACR apart from the oxidation of isoprene; (3) the processing time of the air mass is identical for all three compounds; and (4) only purely chemical reactions are included and the effects of turbulent mixing, horizontal convection and deposition are not accounted for. More description of the calculation is given in Sect. S2.

\section{Results and discussion}

\subsection{Meteorological and chemical conditions}

Figure 2 presents the time series of selected meteorological parameters and trace gases. During the study, the air masses reaching the site were mainly from the south-west and northeast directions. With the change of meteorological conditions, the mixing ratios of air pollutants changed correspondingly. In particular, from 23 to 27 July, concentrations of anthropogenic pollutants (i.e. $\mathrm{SO}_{2}, \mathrm{CO}$ and aromatic VOCs) dramatically increased, and were probably affected by regional transport. During 28-31 July, the relatively higher temperature and lower surface wind enhanced the emissions of isoprene and reduced the dispersion of isoprene and its oxidation products, resulting in the elevated levels of these species in the air. In addition, there was a notable decrease in concentrations of both isoprene and its oxidation products on 2-3 August, likely caused by continuous rain during the typhoon NIDA. The average temperature was $19.2 \pm 0.1^{\circ} \mathrm{C}$ (mean $\pm 95 \%$ confidence interval, the same below) and the relative humidity was $92.1 \pm 0.6 \%$. Discontinuities in the figure mean that either no data were available due to the instrumental calibration and maintenance, or the values were below the MDL for those time periods.

Figure 3 shows the average diurnal patterns of temperature, $\mathrm{O}_{3}, \mathrm{NO}_{2}, \mathrm{NO}$ and $\mathrm{CO}$. Time is given in this paper as LT (Local time: UTC $+8 \mathrm{~h}$ ). During the sampling periods, sunrise and sunset times were about 06:00 and 19:00 LT, respectively. The concentrations of observed $\mathrm{O}_{3}, \mathrm{NO}_{2}, \mathrm{NO}$ and CO ranged from 14.4 to $130.6 \mathrm{ppbv}(53.5 \pm 1.3 \mathrm{ppbv}), 0.9$ to $10.5 \mathrm{ppbv}$ ( $2443 \pm 74 \mathrm{pptv}), 0.6$ to $8.7 \mathrm{ppbv}$ ( $736 \pm 37 \mathrm{pptv})$ and 40.8 to $684.4 \mathrm{ppbv}(266.2 \pm 6.6 \mathrm{ppbv})$, respectively. Similar to previous mountaintop studies, a distinct $\mathrm{O}_{3}$ diurnal variation which featured high levels at night and low levels during the daytime (Zaveri et al., 1995; Gao et al., 2017) was observed in this study, most likely due to a combination of various physical and chemical processes (e.g. boundary layer diurnal cycles, mountain-valley breezes, regional transport and photochemical reactions). Since the $\mathrm{NO}_{2}$ concentrations measured by the molybdenum oxide converter technique can be significantly overestimated in areas far away from fresh $\mathrm{NO}_{x}$ emission sources (Xu et al., 2013), we corrected the observed $\mathrm{NO}_{2}$ by adopting the hourly modification factors (Fig. S1) obtained at Mount Tai (1533 m a.s.1.) in central-eastern China (Xu et al., 2013). The modified $\mathrm{NO}_{2}$ $(889 \pm 27$ pptv) was $1.1-2.5$ times $(1.8 \pm 0.3)$ lower than that observed. Furthermore, anthropogenic tracers showed very low mixing ratios at this site. For example, the ambient aromatic levels at this site were significantly lower compared to the abundances that measured at a regional background site in the PRD (Wu et al., 2016). Toluene was the most abundant ( $154 \pm 20 \mathrm{pptv})$, followed by benzene ( $51 \pm 8 \mathrm{pptv})$, ethylbenzene ( $47 \pm 6 \mathrm{pptv})$ and $m, p$-xylene ( $38 \pm 4 \mathrm{pptv})$.

\subsection{Isoprene and its oxidation products}

The hourly averages of isoprene, MVK and MACR were $287 \pm 32$ pptv (4-2605 pptv), $293 \pm 22$ pptv (16-1244 pptv), $73 \pm 6$ pptv (10-442 pptv), respectively. Their diurnal behaviours are influenced by a number of chemical (e.g. oxidants levels) and meteorological factors (e.g. temperature and sunlight). The hourly averaged daytime isoprene ( $377 \pm$ 46 pptv, $p<0.01)$ and MVK (332 \pm 32 pptv, $p<0.01)$ were both higher than the values in nighttime $(159 \pm 35$ and $252 \pm 28$ pptv, respectively). However, the daytime MACR $(66 \pm 7 \mathrm{pptv})$ was slightly lower than its nighttime value $(81 \pm 10 \mathrm{pptv})$. In addition, the levels of these compounds decreased substantially at 06:00 LT, which could be due to the expansion of the PBL (Fig. S2) and the entrainment of oxidant-rich FT air into the PBL (Vilà-Guerau de Arellano et al., 2011).

Table 1 presents the comparison of measurements in this study with previous studies. Surprisingly, the comparison revealed that the isoprene level in this study was much lower than those observed at other sites with similar types of forest, either in China or around the world, particularly if considering the fact that potentially strong isoprene emitters, like evergreen broad-leaved trees and shrubs, are widely seen in this low latitude subtropical forested region (Bai et al., 2016, 2017). Although the high-altitude feature ( $1690 \mathrm{~m}$ a.s.l.) may lower the observed isoprene levels as compared with the forest canopy underneath the site, it is still interesting to find that the daytime isoprene concentration ( $377 \pm 46 \mathrm{pptv})$ in the hottest months of the year (July-August) was 50\%-100\% lower than the values observed at the same latitude subtropical forested sites in Southern China (e.g. yearly value of $760 \mathrm{pptv}$ at Dinghu Mountain, and summer average of 1028 pptv at a rural park) (Chen et al., 2010; Wu et al., 2016). Furthermore, $\mathrm{O}_{3}$ and $\mathrm{NO}_{x}$ levels at this site were generally higher than the observations available in other forest stud- 

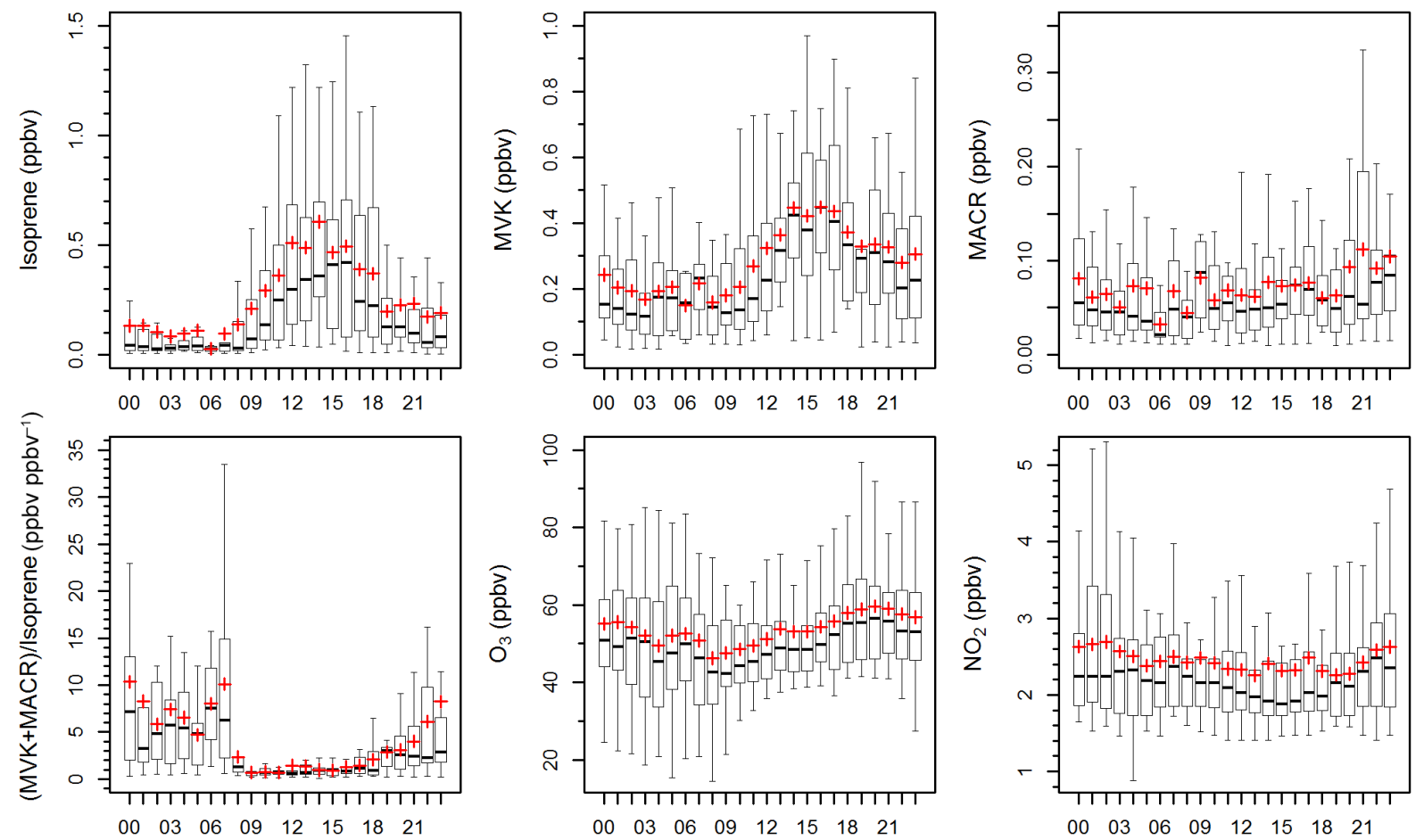

$\begin{array}{llllllll}00 & 03 & 06 & 09 & 12 & 15 & 18 & 21\end{array}$
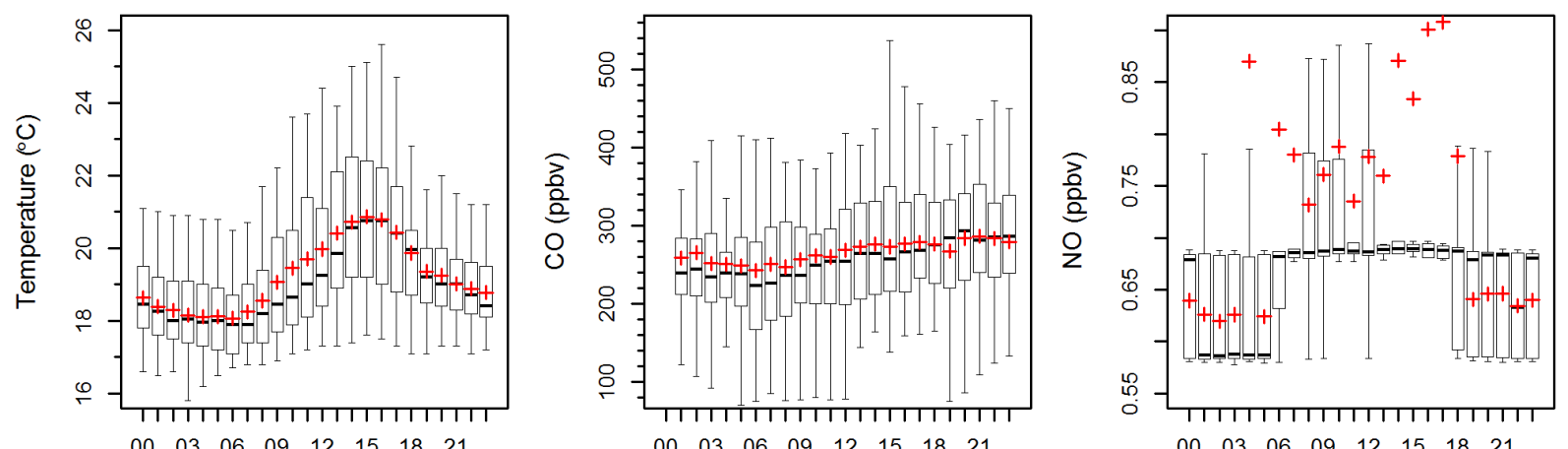

Figure 3. Box and whisker plots of average diurnal patterns of observed isoprene, MVK, MACR, (MVK $+\mathrm{MACR}) /$ isoprene ratios, $\mathrm{O}_{3}$, $\mathrm{NO}_{2}$, temperature, $\mathrm{CO}$ and NO. The $x$ axis is "hour of day". The black thick line and red plus sign represent the median and mean value, respectively.

ies worldwide (Table 1). High abundances of $\mathrm{O}_{3}$ at this site likely indicate strong oxidizing power of the present forest atmospheres. Therefore, these observations may suggest the relevance of the low observed isoprene levels with the complex atmospheric pollution in this region.

Isoprene oxidation was the dominant source of MVK and MACR in this remote forest, with little transported from anthropogenic sources in neighbour cities at night (see discussion in Sect. S3), thus the (MVK + MACR) / isoprene ratio can act as an indicator of the isoprene oxidation degree. In this study, the average (MVK + MACR) / isoprene ratio was $4.0 \pm 0.8$, with the daytime ratio $(1.9 \pm 0.5, p<0.01)$ lower than that $(6.3 \pm 1.4)$ at night. The daytime ratio in this study was much higher than those reported by previous studies (Table 1). For example, the ratio here is about 5 times higher than that observed at a site $21 \mathrm{~m}$ above the canopy reported by Kuhn et al. (2007) in the Amazon rainforest (i.e. $0.3 \pm 0.1$ ). In addition, studies have also shown that enhanced levels of the (MVK + MACR) / isoprene ratio would be expected in environments where the air mass has aged under high-NOx and high-oxidant conditions (Apel et al., 2002). Therefore, this high (MVK + MACR) / isoprene ratio likely suggests that isoprene was highly oxidized at this site due to strong AOC.

\subsection{Atmospheric oxidative capacity}

Above discussions had speculated that the strong AOC might be the main factor contributing to the observed low concentrations of summertime isoprene and 
Table 1. Comparison of average concentrations (in ppbv, mean $\pm 1 \sigma$ standard deviation or $95 \%$ confidence interval) of isoprene, $\mathrm{O}_{3}$, $\mathrm{NO}_{2}$ and NO measured at the Nanling site, as well as (MVK + MACR) / isoprene ratios (ppbv / ppbv) and altitude (m a.s.l.), with other forest or mountaintop sites.

\begin{tabular}{|c|c|c|c|c|c|c|}
\hline Forest type and latitude & Altitude & Isoprene & Ratio $^{\mathrm{a}}$ & $\mathrm{O}_{3}, \mathrm{NO}_{2}, \mathrm{NO}^{\mathrm{b}}$ & Sampling time & References \\
\hline \multirow{3}{*}{ Subtropical $\left(24.70^{\circ} \mathrm{N}\right)$} & \multirow{3}{*}{1690} & $0.377 \pm 0.046$ & $1.9 \pm 0.5$ & $\begin{array}{l}51.9 \pm 1.7 \\
2.39 \pm 0.11 \\
0.80 \pm 0.06\end{array}$ & Daytime (summer) & \multirow{3}{*}{ This study } \\
\hline & & $0.159 \pm 0.035$ & $6.3 \pm 1.4$ & $\begin{array}{l}55.5 \pm 2.1 \\
2.51 \pm 0.10 \\
0.66 \pm 0.05\end{array}$ & Nighttime (summer) & \\
\hline & & $0.287 \pm 0.032$ & $4.0 \pm 0.8$ & $\begin{array}{l}53.5 \pm 1.3 \\
2.44 \pm 0.07 \\
0.74 \pm 0.04\end{array}$ & Daily (summer) & \\
\hline Subtropical $\left(23.17^{\circ} \mathrm{N}\right)$ & 1000 & $0.76 \pm 0.50$ & $-^{\mathrm{c}}$ & - & Daytime (all year) & Wu et al. (2016) \\
\hline Subtropical $\left(22.29^{\circ} \mathrm{N}\right)$ & 507 & $1.028 \pm 0.025$ & - & - & Daytime (summer) & Chen et al. (2010) \\
\hline Subtropical $\left(30.50^{\circ} \mathrm{N}\right)$ & 130 & $0.39 \pm 0.27$ & - & - & Daytime (spring) & Tang et al. (2009) \\
\hline Tropical $\left(18.67^{\circ} \mathrm{N}\right)$ & 820 & $0.55 \pm 0.52$ & - & - & Daytime (wet season) & Tang et al. (2009) \\
\hline Deciduous $\left(22.25^{\circ} \mathrm{N}\right)$ & 80 & $0.370 \pm 0.157$ & - & $\begin{array}{l}42 \pm 22,- \\
2.4 \pm 3.6\end{array}$ & Daytime (all year) & Wang et al. (2005) \\
\hline Mt. Tai $\left(36.25^{\circ} \mathrm{N}\right)$ & 1533 & $0.15 \pm 0.18$ & - & - & Daily (summer) & Zhu et al. (2017) \\
\hline Tibet $\left(36.3^{\circ} \mathrm{N}\right)$ & 3816 & $0.126 \pm 0.287$ & - & $\begin{array}{l}54 \pm 11, \\
3.60 \pm 1.13^{\mathrm{d}}, \\
0.05 \pm 0.03\end{array}$ & Daily (summer) & Xue et al. (2013) \\
\hline Temperate $\left(45.56^{\circ} \mathrm{N}\right)$ & 801 & $1.90 \pm 0.43$ & 0.4 & $-, 1.0,0.1$ & Midday (summer) & Apel et al. (2002) \\
\hline Ponderosa $\left(39.1^{\circ} \mathrm{N}\right)$ & 2840 & $0.148 \pm 0.098$ & - & - & Daily (summer) & Rhew et al. (2017) \\
\hline Deciduous $\left(36.21^{\circ} \mathrm{N}\right)$ & 1100 & $0.743 \pm 0.575$ & 0.6 & - & Daily (summer) & Link et al. (2015) \\
\hline Deciduous $\left(43.93^{\circ} \mathrm{N}\right)$ & 650 & 1.19 & $0.13 \pm 0.05$ & $-,<3,<0.2$ & Daily (summer) & Kalogridis et al. (2014) \\
\hline Deciduous $\left(45.20^{\circ} \mathrm{N}\right)$ & 24 & $1.07 \pm 0.80$ & 0.5 & - & Daily (summer) & Acton et al. (2016) \\
\hline Coniferous $\left(38.90^{\circ} \mathrm{N}\right)$ & 1315 & $0.397 \pm 0.558$ & - & - & Daily (summer) & Dreyfus et al. (2002) \\
\hline Mediterranean $\left(41.78^{\circ} \mathrm{N}\right)$ & 720 & 0.43 & 0.7 & $37.5,1.0,0.8$ & Daily (summer) & Seco et al. (2011) \\
\hline Tropical $\left(4.98^{\circ} \mathrm{N}\right)$ & 426 & $1.4 \pm 1.2$ & $<0.4$ & - & Daily (dry season) & Langford et al. (2010) \\
\hline Tropical $\left(4.98^{\circ} \mathrm{N}\right)$ & 426 & 1.058 & 0.5 & - & Daily (wet season) & Jones et al. (2011) \\
\hline Tropical $\left(2.59^{\circ} \mathrm{S}\right)$ & 103 & $1.66 \pm 0.90$ & - & - & Daytime (wet season) & Alves et al. (2016) \\
\hline Tropical $\left(2.59^{\circ} \mathrm{S}\right)$ & 103 & 3.4 & $0.31 \pm 0.07$ & $15.0,-,-$ & Daytime (dry season) & Kuhn et al. (2007) \\
\hline
\end{tabular}

${ }^{\mathrm{a}}$ Represents the (MVK + MACR) / isoprene ratio. ${ }^{\mathrm{b}}$ Observed data. ${ }^{\mathrm{c}}$ Data not reported or not applicable. ${ }^{\mathrm{d}} \mathrm{NO}_{y}$.

high (MVK + MACR) / isoprene ratios at this subtropical forested mountaintop site. Since in this study we did not monitor oxidative radicals, with which the analysis of AOC could be more reliable, the concentrations of daytime $\mathrm{OH}$ and nocturnal $\mathrm{NO}_{3}$ were modelled by PBM-MCM (Fig. 4).

\subsubsection{Daytime OH}

The average hourly daytime $\mathrm{OH}$ concentration estimated by PBM-MCM at this site was $7.3 \pm 0.5 \times$ $10^{6}$ molecules $\mathrm{cm}^{-3}(0.36 \pm 0.03 \mathrm{pptv})$, with a median value of $7.7 \times 10^{6}$ molecules $\mathrm{cm}^{-3}$. Peaks in concentrations $(14.4 \pm$ $0.8 \times 10^{6}$ molecules $\mathrm{cm}^{-3}$ ) appeared at 12:00 LT when the solar radiation was usually the strongest, and then gradually the concentrations decreased to the lowest levels before sunset. Overall, the calculated $\mathrm{OH}$ levels are consistent with the observed values in the PRD (with average and peak value of $\sim 8 \times 10^{6}$ and $1.5-2.6 \times 10^{7}$ molecules $\mathrm{cm}^{-3}$, respectively) (Xiao et al., 2009; Yang et al., 2017; Hofzumahaus et al., 2009). And the range of estimated mixing ratios of daytime $\mathrm{OH}\left(3.6 \times 10^{5}\right.$ to $1.9 \times 10^{7}$ molecules $\left.\mathrm{cm}^{-3}\right)$ in

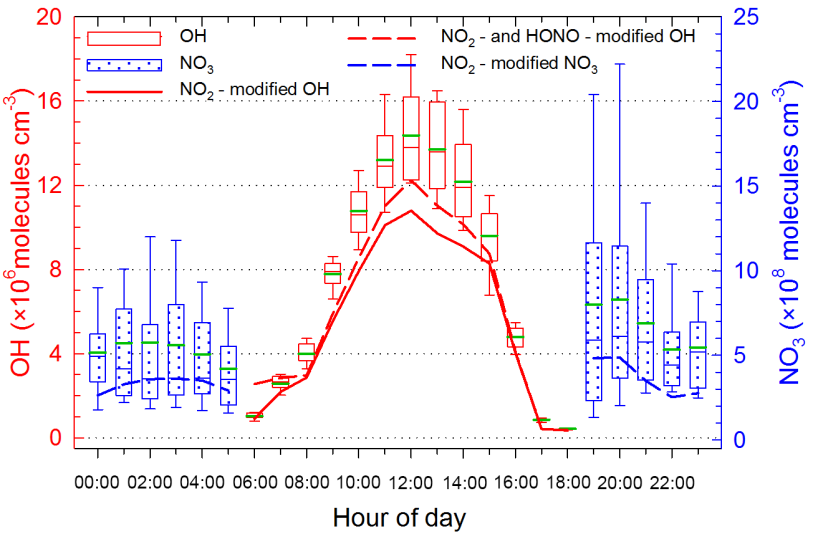

Figure 4. Box and whisker plots of average diurnal patterns of PBM-MCM modelled $\mathrm{OH}$ and $\mathrm{NO}_{3}$ concentrations. The green thick line represents the mean value. Also shown are the results after conducting sensitivity analyses for the model by modifying the mixing ratios of $\mathrm{NO}_{2}$ and $\mathrm{HONO}$. 
this work generally agrees with the daytime levels $\left(3.3 \times 10^{6}\right.$ to $2.6 \times 10^{7}$ molecules $\mathrm{cm}^{-3}$ ) observed at rural sites in the PRD by Xiao et al. (2009), Hofzumahaus et al. (2009) and $\mathrm{Lu}$ et al. (2012). The modelled daytime peak $\mathrm{OH}$ value is much higher than those observed daytime maxima at remote forest areas such as the Blodgett forest in California $\left(4 \times 10^{6}\right.$ molecules $\left.\mathrm{cm}^{-3}\right)$ (Mao et al., 2012), a boreal forest in Finland $\left(3.5 \times 10^{6}\right.$ molecules $\left.\mathrm{cm}^{-3}\right)$ (Hens et al., 2014), a pine forest in Alabama $\left(1 \times 10^{6}\right.$ molecules $\left.\mathrm{cm}^{-3}\right)$ (Feiner et al., 2016) and Mount Tai in Central China (5.7 × $10^{6}$ molecules $\mathrm{cm}^{-3}$ ) (Kanaya et al., 2009). To provide a complement to the PBM-MCM, regional mixing ratios of $\mathrm{OH}$ during 09:00-15:00 LT were calculated by a widely used parameterization method using measured aromatic hydrocarbon ratios, i.e. toluene / benzene (T/B), ethylbenzene/benzene (E/B), and $m, p$-xylene / benzene (X/B) (Fig. S3). The average regional concentrations of $\mathrm{OH}$ during 09:00-15:00 LT was $19.7 \pm 2.3 \times 10^{6}$ molecules $\mathrm{cm}^{-3}$, even higher than the modelled site-level $\mathrm{OH}$ of $11.7 \pm 0.4 \times$ $10^{6}$ molecules $\mathrm{cm}^{-3}$. The high concentrations of $\mathrm{OH}$ in this study indicate that AOC of this forested region was strong and may facilitate the fast oxidation of daytime isoprene.

\subsubsection{Nocturnal $\mathrm{NO}_{3}$}

The estimated average nighttime hourly $\mathrm{NO}_{3}$ level was $6.0 \pm$ $0.5 \times 10^{8}$ molecules $\mathrm{cm}^{-3}(29 \pm 3 \mathrm{pptv})$ which is lower than the value obtained at a semi-rural mountain site $(\sim 40 \mathrm{pptv})$ (Sobanski et al., 2016) and at a high-altitude mountain site ( 70 pptv) (Chen et al., 2011). The $\mathrm{NO}_{3}$ levels in this study were higher than that (11 pptv) modelled by Guo et al. (2012) and comparable to that $(\sim 31 \mathrm{pptv})$ observed by Brown et al. (2016), both at a mountaintop site (640 m a.s.l.) in Hong Kong. The mixing ratios of $\mathrm{NO}_{3}$ started steadily increasing at 19:00 LT, peaked at 20:00 LT, then rose gradually after midnight and peaked again at 02:00 LT of the next day. The nocturnal variation of $\mathrm{NO}_{3}$ is similar to that of $\mathrm{O}_{3}$ (peak at 20:00 LT). At the Nanling site, the average nighttime mixing ratios of $\mathrm{NO}_{2}(2.5 \pm 0.1 \mathrm{ppbv})$ and $\mathrm{O}_{3}(55.5 \pm 2.1 \mathrm{ppbv})$ were relatively high when compared with other remote forest sites $\left(\mathrm{NO}_{2}<1 \mathrm{ppbv}, \mathrm{O}_{3}<30 \mathrm{ppbv}\right.$ ), which provided more favourable conditions for the $\mathrm{NO}_{3}$ formation. In addition, in the surface layer of polluted areas, $\mathrm{NO}_{3}$ is generally low due to the existence of continuously anthropogenic NO as an important $\mathrm{NO}_{3}$ sink; however, in remote or high-altitude mountain regions with cleaner air aloft (e.g. in the upper PBL or lower FT), higher $\mathrm{NO}_{3}$ levels are often observed (Chen et al., 2011; Sobanski et al., 2016; H. C. Wang et al., 2017). The vertical profiles of $\mathrm{NO}_{3}$ obtained by a number of studies have suggested that the $\mathrm{NO}_{3}$ concentration increases with altitude, with a significant fraction existing in the upper PBL or lower FT (Fish et al., 1999; Allan et al., 2002; Friedeburg et al., 2002; Stutz et al., 2004). This is consistent with our results obtained at this high-altitude mountain site. Therefore, the relatively high nighttime $\mathrm{NO}_{3}$ concentrations at this high-altitude mountain site may lead to fast decay of daytime residual isoprene and consequently contribute to MVK and MACR formation.

\subsubsection{Uncertainty analysis}

Three issues should be noted in applying PBM-MCM to evaluate the AOC in the present study. First, the $\mathrm{NO}_{2}$ concentrations, an important input into PBM-MCM, may be significantly overestimated at this remote mountaintop site that receives a considerable amount of photochemically aged air (Xu et al., 2013). Thus we conducted sensitivity analyses of modelled $\mathrm{OH}$ and $\mathrm{NO}_{3}$ with artificially reduced $\mathrm{NO}_{2}$ concentrations for the period of 11-15 August 2016. The $\mathrm{OH}$ and $\mathrm{NO}_{3}$ concentrations decrease with cutting $\mathrm{NO}_{2}$ (Fig. S4). According to a recent study conducted at Mount Tai (Xu et al., 2013), we assumed the daytime and nighttime $\mathrm{NO}_{2}$ measurements were overestimated by $64.4 \% \pm$ $2.9 \%$ and $62.4 \% \pm 3.0 \%$, respectively. Thus the recalculated mean daytime $\mathrm{OH}$ concentration would decrease from $7.3 \pm 0.5 \times 10^{6}$ to $5.5 \pm 0.4 \times 10^{6}$ molecules $\mathrm{cm}^{-3}$, with a reduction rate of $23.8 \% \pm 6.2 \%$. And for nighttime $\mathrm{NO}_{3}$, the reduction rate was $41.5 \% \pm 5.2 \%$ (from $6.0 \pm 0.5 \times 10^{8}$ to $3.5 \pm 0.3 \times 10^{8}$ molecules $\mathrm{cm}^{-3}$ ). Second, a number of studies have shown that HONO plays an important role in daytime $\mathrm{OH}$ formation (Xue et al., 2014b). As the concentrations of HONO were not measured in the sampling periods, we therefore conducted sensitivity analyses by using a two-day (13 and 15 August) dataset coupled with the average diurnal profiles of HONO observed at a background site (Hok Tsui) in Hong Kong in autumn 2012 (Zha, 2015). The results showed that daytime $\mathrm{OH}$ concentrations with $\mathrm{HONO}$ considered was $22 \% \pm 19 \%$ higher than that without HONO (Fig. S5). Finally, the dinitrogen pentoxides $\left(\mathrm{N}_{2} \mathrm{O}_{5}\right)$ that formed from the oxidation of $\mathrm{NO}_{2}$ by $\mathrm{NO}_{3}$ can be taken up onto aerosols via heterogeneous reactions, which is an important sink of $\mathrm{NO}_{2}$ and $\mathrm{O}_{3}$ at night and can compete with the reactions of $\mathrm{NO}_{3}$ with isoprene (Xue et al., 2014b; Brown et al., 2016; Millet et al., 2016). Unfortunately, we were not able to quantitatively take into account this important mechanism in this study, and further studies are needed to make up this limitation. Overall, current PBM-MCM may have $19 \% \pm 9 \%$ and $73 \% \pm 16 \%$ overestimation of the daytime $\mathrm{OH}$ and nighttime $\mathrm{NO}_{3}$ concentrations, respectively. Therefore, the PBM-MCM needs improvement and further optimization for its application under the present forested environments.

\subsection{Linking observed and initial isoprene}

The above discussion kindly suggests the strong AOC might be the main factor contributing to the observed low-level isoprene and high (MVK + MACR) / isoprene ratios in summer. To further confirm this, the initial isoprene, which is the total amount of emitted isoprene, was calculated to verify the magnitude of isoprene oxidation. Furthermore, to obtain the 

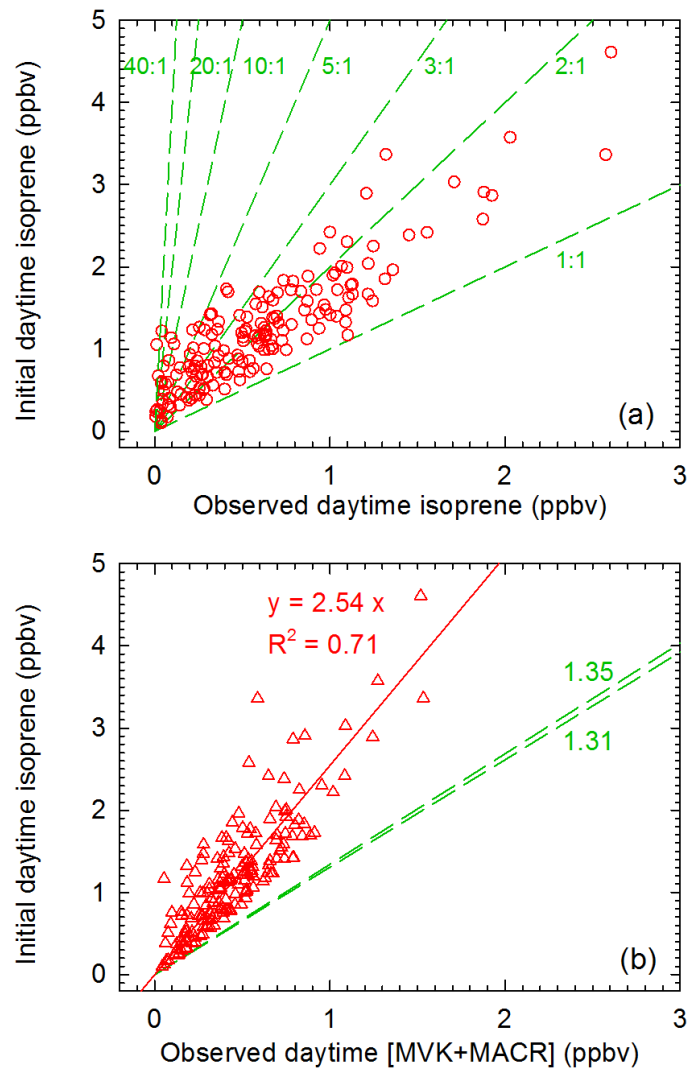

Figure 5. (a) Comparison of observed and initial isoprene mixing ratios during the day. Green dashed lines denote slopes for different ratios of initial to observed isoprene. (b) Relationship between initial isoprene and observed [MVK + MACR] during the day. The green dashed lines denote slopes for different yields of (MVK + MACR) of the OH-initiated oxidation of isoprene for the ranges of the observed NO distribution (Fig. S7).

oxidation rate of isoprene, the atmospheric reaction time of isoprene can be thereby derived by introducing the estimated concentrations of $\mathrm{OH}$ and $\mathrm{NO}_{3}$.

Initial isoprene was calculated from the observed $\mathrm{MVK} /$ isoprene and MACR/isoprene ratios. Figure 5a shows plots of the initial isoprene versus the observed isoprene $\left(\mathrm{ISO}_{\mathrm{i}} / \mathrm{ISO}_{\mathrm{o}}\right)$ during the day. The initial mixing ratios of daytime isoprene ( $1213 \pm 108 \mathrm{pptv})$ were much higher than the observed values $(377 \pm 46 \mathrm{pptv})$. It is noteworthy that the initial nighttime isoprene by this approach may be overestimated due to the daytime residual MVK and MACR which remained into the night (Fig. S6). The daytime initial mixing ratios of isoprene are 1-40 times the observed levels, with median and mean values of 2.1 and 4.3 , respectively. The $\mathrm{ISO}_{\mathrm{i}} / \mathrm{ISO}_{\mathrm{o}}$ in this study is comparable with that (ranged from 2 to 40 , with a mean value of $\sim 4$ ) obtained in the southeastern US, a photochemistry-active and strong isopreneemitting region (Wolfe et al., 2016). Scatter plots of calculated initial isoprene versus measured MVK + MACR dur-

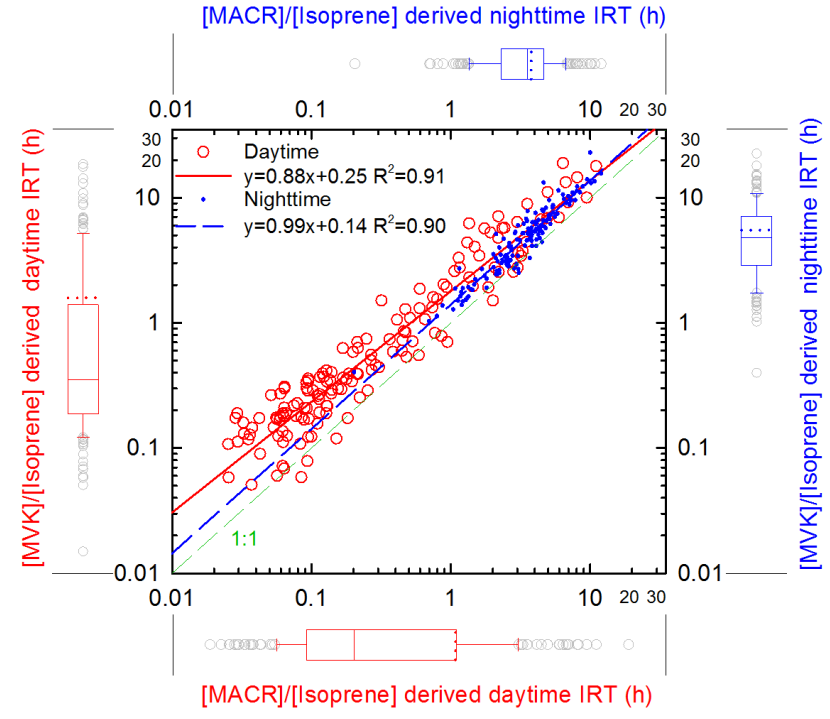

Figure 6. Isoprene reaction time (IRT) derived from $[\mathrm{MVK}] /$ [isoprene] and [MACR]/[isoprene] based on the modelled $\mathrm{OH}$ and $\mathrm{NO}_{3}$ concentrations. The green dashed line denotes a $1: 1$ relationship. Next to axes are the box and whisker plots of each result, and the dotted lines denote the mean values.

ing daytime hours are also given in Fig. 5b, and a good correlation $\left(R^{2}=0.71\right)$ was obtained. Since the slope is related to the yield of (MVK + MACR) from $\mathrm{OH}$-initiated reaction of isoprene and further oxidation of those two products with $\mathrm{OH}$, data points which are consistently over the dashed line are likely due to chemical loss of MVK and MACR and/or the influence of continuous emissions of isoprene. These results further confirmed that isoprene was highly oxidized in the air masses, leading to the observed low-level isoprene and high (MVK + MACR) / isoprene ratios.

Figure 6 shows the derived isoprene reaction times (IRT) from [MVK] / [isoprene] and [MACR] / [isoprene], respectively. IRT derived from the two ratios exhibit a significant linear correlation $\left(R^{2}=0.91\right.$ and 0.90 for daytime and nighttime, respectively). The IRT derived from [MACR]/[isoprene] is $13 \%$ lower than that from [MVK] / [isoprene] on average, and we use the mean of these two values. The median and mean IRT during the day is 0.27 and $1.39 \mathrm{~h}$, respectively, with 4.10 and $4.49 \mathrm{~h}$ at night. The median daytime reaction time $(0.27 \mathrm{~h})$ of measured isoprene was slightly lower than the theoretical lifetime of isoprene $(0.40 \mathrm{~h}$ at $12 \mathrm{~h}$ daytime averaged $[\mathrm{OH}]=$ $8.0 \times 10^{6}$ molecules $\mathrm{cm}^{-3}$ ). The short reaction time of isoprene indicates fast isoprene oxidation at this mountaintop site. 


\section{Conclusions}

Isoprene and its major intermediate oxidation products MVK and MACR were simultaneously observed in the summer of 2016 at a forested mountaintop site located at the Nanling Mountains in southern China. Although the sampling site was surrounded with subtropical evergreen broadleaved trees which are strong isoprene emitters, the average daytime isoprene level $(377 \pm 46 \mathrm{pptv})$ was found to be significantly lower than other forest studies, while the $(\mathrm{MVK}+\mathrm{MACR}) /$ isoprene ratio $(1.9 \pm 0.5)$ and $\mathrm{O}_{3}(51.9 \pm$ $1.7 \mathrm{ppbv}$ ) were relatively higher. Based on the observations, we hypothesized that the lower isoprene levels in the study forest might be attributable to a strong AOC in relation to the elevated regional complex air pollution in southern China.

To validate this hypothesis, high daytime $\mathrm{OH}$ and nighttime $\mathrm{NO}_{3}$ radical concentrations were estimated by using a PBM-MCM and a parameterization method. Results from the two approaches are comparable to those observations conducted in the PRD. Although certain uncertainties remained in the present modelling, all radical estimations demonstrated the strong AOC in this subtropical forested region, which may facilitate fast isoprene oxidation and subsequently contribute to the MVK and MACR formation. In addition, it was found that initial daytime isoprene was 140 times the observed isoprene, with a mean value of 4.3, which is comparable to the photochemistry-active and strong isoprene-emitting south-eastern US. Based on the estimated radical concentrations, short daytime atmospheric reaction time $(0.27 \mathrm{~h})$ was subsequently calculated for isoprene during the day. All these indicate that the isoprene was rapidly and highly oxidized over this high-oxidant forest.

To the best of our knowledge, this is the first direct measurement of isoprene and its first-stage oxidation products at this remote, subtropical forested and high-altitude mountain location in southern China. This work highlighted that the air quality and ecological environment of this forest were affected by the highly polluted air from the PRD, particularly the oxidation capacity of the forest's atmosphere was significantly enhanced. Furthermore, recent long-term observational studies in the PRD (Wang et al., 2009; Y. Wang et al., 2017; T. Wang et al., 2017; Xue et al., 2014a) have indicated the increasing trends of surface $\mathrm{O}_{3}$, another indicator of the regional AOC. Therefore, continued field observations and further studies are crucial for understanding the relatively high oxidative capacity in this forested region. The feedback of forest ecosystems to the increasing AOC in southern China warrants further studies.

Data availability. The data set is available to the community and can be accessed by request from Boguang Wang (tbongue@jnu.edu.cn).
Supplement. The supplement related to this article is available online at: https://doi.org/10.5194/acp-18-14417-2018-supplement.

Author contributions. BW and HW planned and organized the study. DG and HW performed the data analysis and wrote the manuscript. YW and SZ assisted heavily with the model development and data analysis. DG and SZ conducted the atmospheric measurements. SCL, YZ, LM, HG, MS, CH, DC, LH and LZ provided useful insights in data analysis and contributed to the writing of the manuscript.

DG and HW contributed equally to this work.

Competing interests. The authors declare that they have no conflict of interest.

Special issue statement. This article is part of the special issue "Regional transport and transformation of air pollution in eastern China". It is not associated with a conference.

Acknowledgements. This work was supported by the National Natural Science Foundation of China (91544215, 41373116 and 41877370) and the Science and Technology Planning Project of Guangdong Province of China (2014B090901058). The authors gratefully acknowledge Alfred Wiedensohler for his insightful suggestions on the manuscript. Appreciation is expressed to Jianmin Chen and the anonymous reviewers for their particularly helpful reviews of our manuscript. We thank Jie Ou and Yu Zheng from Shaoguan Environmental Monitoring Central Station for the help during the sampling campaign. We also thank Guangdong Tianjingshan Forest Farm for their help during the field sampling. We also acknowledge David Carslaw for the provision of the $\mathrm{R}$ package "openair" (http://www.openair-project.org, last access: 17 August 2017) used in this publication. The authors also gratefully acknowledge Tao Wang's group of the Hong Kong Polytechnic University for the provision of the average diurnal profiles of HONO at Hok Tsui. We also thank the Team BlackTree for providing an aerial photo of the Nanling site in Fig. 1c. Very special thanks also go to Zhengquan Zhu's family for their warm help during the field campaign.

Edited by: Jianmin Chen

Reviewed by: three anonymous referees

\section{References}

Acton, W. J. F., Schallhart, S., Langford, B., Valach, A., Rantala, P., Fares, S., Carriero, G., Tillmann, R., Tomlinson, S. J., Dragosits, U., Gianelle, D., Hewitt, C. N., and Nemitz, E.: Canopyscale flux measurements and bottom-up emission estimates of volatile organic compounds from a mixed oak and hornbeam forest in northern Italy, Atmos. Chem. Phys., 16, 7149-7170, https://doi.org/10.5194/acp-16-7149-2016, 2016. 
Allan, B. J., Plane, J. M. C., Coe, H., and Shillito, J.: Observations of $\mathrm{NO}_{3}$ concentration profiles in the troposphere, J. Geophys. Res.-Atmos., 107, ACH 4588, https://doi.org/10.1029/2002jd002112, 2002.

Alves, E. G., Jardine, K., Tota, J., Jardine, A., Yãnez-Serrano, A. M., Karl, T., Tavares, J., Nelson, B., Gu, D., Stavrakou, T., Martin, S., Artaxo, P., Manzi, A., and Guenther, A.: Seasonality of isoprenoid emissions from a primary rainforest in central Amazonia, Atmos. Chem. Phys., 16, 3903-3925, https://doi.org/10.5194/acp-16-3903-2016, 2016.

Apel, E. C., Riemer, D. D., Hills, A., Baugh, W., Orlando, J., Faloona, I., Tan, D., Brune, W., Lamb, B., Westberg, H., Carroll, M. A., Thornberry, T., and Geron, C. D.: Measurement and interpretation of isoprene fluxes and isoprene, methacrolein, and methyl vinyl ketone mixing ratios at the PROPHET site during the 1998 Intensive, J. Geophys. Res.-Atmos., 107, 4034, https://doi.org/10.1029/2000jd000225, 2002.

Bai, J., Guenther, A., Turnipseed, A., Duhl, T., and Greenberg, J.: Seasonal and interannual variations in whole-ecosystem BVOC emissions from a subtropical plantation in China, Atmos. Environ., 161, 176-190, https://doi.org/10.1016/j.atmosenv.2017.05.002, 2017.

Bai, J. H., Guenther, A., Turnipseed, A., Duhl, T., Yu, S. Q., and Wang, B.: Seasonal variations in wholeecosystem BVOC emissions from a subtropical bamboo plantation in China, Atmos. Environ., 124, 12-21, https://doi.org/10.1016/j.atmosenv.2015.11.008, 2016.

Brown, S. S., Dube, W. P., Tham, Y. J., Zha, Q. Z., Xue, L. K., Poon, S., Wang, Z., Blake, D. R., Tsui, W., Parrish, D. D., and Wang, T.: Nighttime chemistry at a high altitude site above Hong Kong, J. Geophys. Res.-Atmos., 121, 2457-2475, https://doi.org/10.1002/2015jd024566, 2016.

Chan, C. K. and Yao, X.: Air pollution in mega cities in China, Atmos. Environ., 42, 1-42, https://doi.org/10.1016/j.atmosenv.2007.09.003, 2008.

Chen, C. M., Cageao, R. P., Lawrence, L., Stutz, J., Salawitch, R. J., Jourdain, L., Li, Q., and Sander, S. P.: Diurnal variation of midlatitudinal $\mathrm{NO}_{3}$ column abundance over table mountain facility, California, Atmos. Chem. Phys., 11, 963-978, https://doi.org/10.5194/acp-11-963-2011, 2011.

Chen, H. W., Ho, K. F., Lee, S. C., and Nichol, J. E.: Biogenic volatile organic compounds (BVOC) in ambient air over Hong Kong: analytical methodology and field measurement, Int. J. Environ. Anal. Chem. 90, 988-998, https://doi.org/10.1080/03067310903108360, 2010.

Cheng, H. R., Guo, H., Saunders, S. M., Lam, S. H. M., Jiang, F., Wang, X. M., Simpson, I. J., Blake, D. R., Louie, P. K. K., and Wang, T. J.: Assessing photochemical ozone formation in the Pearl River Delta with a photochemical trajectory model, Atmos. Environ., 44, 4199-4208, https://doi.org/10.1016/j.atmosenv.2010.07.019, 2010.

Claeys, M., Graham, B., Vas, G., Wang, W., Vermeylen, R., Pashynska, V., Cafmeyer, J., Guyon, P., Andreae, M. O., Artaxo, P., and Maenhaut, W.: Formation of secondary organic aerosols through photooxidation of isoprene, Science, 303, 1173-1176, https://doi.org/10.1126/science.1092805, 2004.

Dreyfus, G. B., Schade, G. W., and Goldstein, A. H.: Observational constraints on the contribution of isoprene oxidation to ozone production on the western slope of the
Sierra Nevada, California, J. Geophys. Res.-Atmos., 107, 4365, https://doi.org/10.1029/2001jd001490, 2002.

Feiner, P. A., Brune, W. H., Miller, D. O., Zhang, L., Cohen, R. C., Romer, P. S., Goldstein, A. H., Keutsch, F. N., Skog, K. M., Wennberg, P. O., Nguyen, T. B., Teng, A. P., DeGouw, J., Koss, A., Wild, R. J., Brown, S. S., Guenther, A., Edgerton, E., Baumann, K., and Fry, J. L.: Testing Atmospheric Oxidation in an Alabama Forest, J. Atmos. Sci., 73, 4699-4710, https://doi.org/10.1175/jas-d-16-0044.1, 2016.

Fish, D. J., Shallcross, D. E., and Jones, R. L.: The vertical distribution of $\mathrm{NO}_{3}$ in the atmospheric boundary layer, Atmos. Environ., 33, 687-691, https://doi.org/10.1016/S1352-2310(98)00332-X, 1999.

Friedeburg, C. V., Wagner, T., Geyer, A., Kaiser, N., Vogel, B., Vogel, H., and Platt, U.: Derivation of tropospheric $\mathrm{NO}_{3}$ profiles using off-axis differential optical absorption spectroscopy measurements during sunrise and comparison with simulations, J. Geophys. Res., 107, 4168, https://doi.org/10.1029/2001JD000481, 2002.

Fuchs, H., Hofzumahaus, A., Rohrer, F., Bohn, B., Brauers, T., Dorn, H. P., Haseler, R., Holland, F., Kaminski, M., Li, X., Lu, K., Nehr, S., Tillmann, R., Wegener, R., and Wahner, A.: Experimental evidence for efficient hydroxyl radical regeneration in isoprene oxidation, Nat. Geosci., 6, 1023-1026, https://doi.org/10.1038/ngeo1964, 2013.

Gao, J., Zhu, B., Xiao, H., Kang, H., Hou, X., Yin, Y., Zhang, L., and Miao, Q.: Diurnal variations and source apportionment of ozone at the summit of Mount Huang, a rural site in Eastern China, Environ. Pollut., 222, 513-522, https://doi.org/10.1016/j.envpol.2016.11.031, 2017.

Gu, D., Guenther, A. B., Shilling, J. E., Yu, H., Huang, M., Zhao, C., Yang, Q., Martin, S. T., Artaxo, P., Kim, S., Seco, R., Stavrakou, T., Longo, K. M., Tota, J., de Souza, R. A. F., Vega, O., Liu, Y., Shrivastava, M., Alves, E. G., Santos, F. C., Leng, G., and Hu, Z.: Airborne observations reveal elevational gradient in tropical forest isoprene emissions, Nat. Commun., 8, 15541, https://doi.org/10.1038/ncomms15541, 2017.

Guenther, A., Karl, T., Harley, P., Wiedinmyer, C., Palmer, P. I., and Geron, C.: Estimates of global terrestrial isoprene emissions using MEGAN (Model of Emissions of Gases and Aerosols from Nature), Atmos. Chem. Phys., 6, 3181-3210, https://doi.org/10.5194/acp-6-3181-2006, 2006.

Guenther, A. B., Jiang, X., Heald, C. L., Sakulyanontvittaya, T., Duhl, T., Emmons, L. K., and Wang, X.: The Model of Emissions of Gases and Aerosols from Nature version 2.1 (MEGAN2.1): an extended and updated framework for modeling biogenic emissions, Geosci. Model Dev., 5, 1471-1492, https://doi.org/10.5194/gmd-5-1471-2012, 2012.

Guo, H., Ling, Z. H., Simpson, I. J., Blake, D. R., and Wang, D. W.: Observations of isoprene, methacrolein (MAC) and methyl vinyl ketone (MVK) at a mountain site in Hong Kong, J. Geophys. Res.-Atmos., 117, D19303, https://doi.org/10.1029/2012jd017750, 2012.

Guo, H., Ling, Z. H., Cheung, K., Jiang, F., Wang, D. W., Simpson, I. J., Barletta, B., Meinardi, S., Wang, T. J., Wang, X. M., Saunders, S. M., and Blake, D. R.: Characterization of photochemical pollution at different elevations in mountainous areas in Hong Kong, Atmos. Chem. Phys., 13, 3881-3898, https://doi.org/10.5194/acp-13-3881-2013, 2013. 
Hens, K., Novelli, A., Martinez, M., Auld, J., Axinte, R., Bohn, B., Fischer, H., Keronen, P., Kubistin, D., Nölscher, A. C., Oswald, R., Paasonen, P., Petäjä, T., Regelin, E., Sander, R., Sinha, V., Sipilä, M., Taraborrelli, D., Tatum Ernest, C., Williams, J., Lelieveld, J., and Harder, H.: Observation and modelling of $\mathrm{HO}_{x}$ radicals in a boreal forest, Atmos. Chem. Phys., 14, 8723-8747, https://doi.org/10.5194/acp-14-8723-2014, 2014.

Hewitt, C. N., Ashworth, K., Boynard, A., Guenther, A., Langford, B., MacKenzie, A. R., Misztal, P. K., Nemitz, E., Owen, S. M., Possell, M., Pugh, T. A. M., Ryan, A. C., and Wild, O.: Ground-level ozone influenced by circadian control of isoprene emissions, Nat. Geosci., 4, 671-674, https://doi.org/10.1038/ngeo1271, 2011.

Hofzumahaus, A., Rohrer, F., Lu, K., Bohn, B., Brauers, T., Chang, C. C., Fuchs, H., Holland, F., Kita, K., Kondo, Y., Li, X., Lou, S., Shao, M., Zeng, L., Wahner, A., and Zhang, Y.: Amplified trace gas removal in the troposphere, Science, 324, 1702-1704, https://doi.org/10.1126/science.1164566, 2009.

Jenkin, M. E., Saunders, S. M., and Pilling, M. J.: The tropospheric degradation of volatile organic compounds: A protocol for mechanism development, Atmos. Environ., 31, 81-104, 1997.

Jenkin, M. E., Saunders, S. M., Wagner, V., and Pilling, M. J.: Protocol for the development of the Master Chemical Mechanism, MCM v3 (Part B): tropospheric degradation of aromatic volatile organic compounds, Atmos. Chem. Phys., 3, 181-193, https://doi.org/10.5194/acp-3-181-2003, 2003.

Jenkin, M. E., Young, J. C., and Rickard, A. R.: The MCM v3.3.1 degradation scheme for isoprene, Atmos. Chem. Phys., 15, 11433-11459, https://doi.org/10.5194/acp-15-11433-2015, 2015.

Jones, C. E., Hopkins, J. R., and Lewis, A. C.: In situ measurements of isoprene and monoterpenes within a south-east Asian tropical rainforest, Atmos. Chem. Phys., 11, 6971-6984, https://doi.org/10.5194/acp-11-6971-2011, 2011.

Kalogridis, C., Gros, V., Sarda-Esteve, R., Langford, B., Loubet, B., Bonsang, B., Bonnaire, N., Nemitz, E., Genard, A.-C., Boissard, C., Fernandez, C., Ormeño, E., Baisnée, D., Reiter, I., and Lathière, J.: Concentrations and fluxes of isoprene and oxygenated VOCs at a French Mediterranean oak forest, Atmos. Chem. Phys., 14, 10085-10102, https://doi.org/10.5194/acp-14-100852014, 2014.

Kanaya, Y., Pochanart, P., Liu, Y., Li, J., Tanimoto, H., Kato, S., Suthawaree, J., Inomata, S., Taketani, F., Okuzawa, K., Kawamura, K., Akimoto, H., and Wang, Z. F.: Rates and regimes of photochemical ozone production over Central East China in June 2006: a box model analysis using comprehensive measurements of ozone precursors, Atmos. Chem. Phys., 9, 7711-7723, https://doi.org/10.5194/acp-9-7711-2009, 2009.

Kim, S., Kim, S.-Y., Lee, M., Shim, H., Wolfe, G. M., Guenther, A. B., He, A., Hong, Y., and Han, J.: Impact of isoprene and HONO chemistry on ozone and OVOC formation in a semirural South Korean forest, Atmos. Chem. Phys., 15, 4357-4371, https://doi.org/10.5194/acp-15-4357-2015, 2015.

Kuhn, U., Andreae, M. O., Ammann, C., Araújo, A. C., Brancaleoni, E., Ciccioli, P., Dindorf, T., Frattoni, M., Gatti, L. V., Ganzeveld, L., Kruijt, B., Lelieveld, J., Lloyd, J., Meixner, F. X., Nobre, A. D., Pöschl, U., Spirig, C., Stefani, P., Thielmann, A., Valentini, R., and Kesselmeier, J.: Isoprene and monoterpene fluxes from Central Amazonian rainforest inferred from tower- based and airborne measurements, and implications on the atmospheric chemistry and the local carbon budget, Atmos. Chem. Phys., 7, 2855-2879, https://doi.org/10.5194/acp-7-2855-2007, 2007.

Langford, B., Misztal, P. K., Nemitz, E., Davison, B., Helfter, C., Pugh, T. A. M., MacKenzie, A. R., Lim, S. F., and Hewitt, C. N.: Fluxes and concentrations of volatile organic compounds from a South-East Asian tropical rainforest, Atmos. Chem. Phys., 10, 8391-8412, https://doi.org/10.5194/acp-10-8391-2010, 2010.

Lelieveld, J., Butler, T. M., Crowley, J. N., Dillon, T. J., Fischer, H., Ganzeveld, L., Harder, H., Lawrence, M. G., Martinez, M., Taraborrelli, D., and Williams, J.: Atmospheric oxidation capacity sustained by a tropical forest, Nature, 452, 737-740, https://doi.org/10.1038/nature06870, 2008.

Li, Z., Xue, L., Yang, X., Zha, Q., Tham, Y. J., Yan, C., Louie, P. K. K., Luk, C. W. Y., Wang, T., and Wang, W.: Oxidizing capacity of the rural atmosphere in Hong Kong, Southern China, Sci. Total Environ., 612, 1114-1122, https://doi.org/10.1016/j.scitotenv.2017.08.310, 2018.

Ling, Z. H., Guo, H., Lam, S. H. M., Saunders, S. M., and Wang, T.: Atmospheric photochemical reactivity and ozone production at two sites in Hong Kong: Application of a master chemical mechanism - photochemical box model, J. Geophys. Res.-Atmos., 119, 10567-10582, https://doi.org/10.1002/2014JD021794, 2014.

Link, M., Zhou, Y., Taubman, B., Sherman, J., Morrow, H., Krintz, I., Robertson, L., Cook, R., Stocks, J., West, M., and Sive, B.: A characterization of volatile organic compounds and secondary organic aerosol at a mountain site in the Southeastern United States, J. Atmos. Chem., 72, 81-104, https://doi.org/10.1007/s10874-015-9305-5, 2015.

Liu, Y., Brito, J., Dorris, M. R., Rivera-Rios, J. C., Seco, R., Bates, K. H., Artaxo, P., Duvoisin Jr., S.,, Keutsch, F. N., Kim, S., Goldstein, A. H., Guenther, A. B., Manzi, A. O., Souza, R. A., Springston, S. R., Watson, T. B., McKinney, K. A., and Martin, S. T.: Isoprene photochemistry over the Amazon rainforest, P. Natl. Acad. Sci. USA, 113, 6125-6130, https://doi.org/10.1073/pnas.1524136113, 2016.

Liu, Y., Seco, R., Kim, S., Guenther, A. B., Goldstein, A. H., Keutsch, F. N., Springston, S. R., Watson, T. B., Artaxo, P., Souza, R. A. F., McKinney, K. A., and Martin, S. T.: Isoprene photo-oxidation products quantify the effect of pollution on hydroxyl radicals over Amazonia, Sci. Adv., 4, eaar2547, https://doi.org/10.1126/sciadv.aar2547, 2018.

Lu, K. D., Rohrer, F., Holland, F., Fuchs, H., Bohn, B., Brauers, T., Chang, C. C., Häseler, R., Hu, M., Kita, K., Kondo, Y., Li, X., Lou, S. R., Nehr, S., Shao, M., Zeng, L. M., Wahner, A., Zhang, Y. H., and Hofzumahaus, A.: Observation and modelling of $\mathrm{OH}$ and $\mathrm{HO}_{2}$ concentrations in the Pearl River Delta 2006: a missing $\mathrm{OH}$ source in a VOC rich atmosphere, Atmos. Chem. Phys., 12, 1541-1569, https://doi.org/10.5194/acp-12-1541-2012, 2012

Lu, K. D., Rohrer, F., Holland, F., Fuchs, H., Brauers, T., Oebel, A., Dlugi, R., Hu, M., Li, X., Lou, S. R., Shao, M., Zhu, T., Wahner, A., Zhang, Y. H., and Hofzumahaus, A.: Nighttime observation and chemistry of $\mathrm{HO}_{x}$ in the Pearl River Delta and Beijing in summer 2006, Atmos. Chem. Phys., 14, 4979-4999, https://doi.org/10.5194/acp-14-4979-2014, 2014

Mao, J., Ren, X., Zhang, L., Van Duin, D. M., Cohen, R. C., Park, J.-H., Goldstein, A. H., Paulot, F., Beaver, M. R., Crounse, J. 
D., Wennberg, P. O., DiGangi, J. P., Henry, S. B., Keutsch, F. N., Park, C., Schade, G. W., Wolfe, G. M., Thornton, J. A., and Brune, W. H.: Insights into hydroxyl measurements and atmospheric oxidation in a California forest, Atmos. Chem. Phys., 12, 8009-8020, https://doi.org/10.5194/acp-12-8009-2012, 2012.

Millet, D. B., Baasandorj, M., Hu, L., Mitroo, D., Turner, J., and Williams, B. J.: Nighttime Chemistry and Morning Isoprene Can Drive Urban Ozone Downwind of a Major Deciduous Forest, Environ. Sci. Technol., 50, 4335-4342, https://doi.org/10.1021/acs.est.5b06367, 2016.

Ng, N. L., Brown, S. S., Archibald, A. T., Atlas, E., Cohen, R. C., Crowley, J. N., Day, D. A., Donahue, N. M., Fry, J. L., Fuchs, H., Griffin, R. J., Guzman, M. I., Herrmann, H., Hodzic, A., Iinuma, Y., Jimenez, J. L., Kiendler-Scharr, A., Lee, B. H., Luecken, D. J., Mao, J., McLaren, R., Mutzel, A., Osthoff, H. D., Ouyang, B., Picquet-Varrault, B., Platt, U., Pye, H. O. T., Rudich, Y., Schwantes, R. H., Shiraiwa, M., Stutz, J., Thornton, J. A., Tilgner, A., Williams, B. J., and Zaveri, R. A.: Nitrate radicals and biogenic volatile organic compounds: oxidation, mechanisms, and organic aerosol, Atmos. Chem. Phys., 17, 2103-2162, https://doi.org/10.5194/acp-17-2103-2017, 2017.

Orlando, J. J. and Tyndall, G. S.: Laboratory studies of organic peroxy radical chemistry: an overview with emphasis on recent issues of atmospheric significance, Chem. Soc. Rev., 41, 62946317, https://doi.org/10.1039/c2cs35166h, 2012.

Parrish, D. D., Stohl, A., Forster, C., Atlas, E. L., Blake, D. R., Goldan, P. D., Kuster, W. C., and de Gouw, J. A.: Effects of mixing on evolution of hydrocarbon ratios in the troposphere, J. Geophys. Res.-Atmos., 112, D10S34, https://doi.org/10.1029/2006jd007583, 2007.

Paulot, F., Crounse, J. D., Kjaergaard, H. G., Kurten, A., St Clair, J. M., Seinfeld, J. H., and Wennberg, P. O.: Unexpected epoxide formation in the gas-phase photooxidation of isoprene, Science, 325, 730-733, https://doi.org/10.1126/science.1172910, 2009.

Perring, A. E., Wisthaler, A., Graus, M., Wooldridge, P. J., Lockwood, A. L., Mielke, L. H., Shepson, P. B., Hansel, A., and Cohen, R. C.: A product study of the isoprene $+\mathrm{NO}_{3}$ reaction, Atmos. Chem. Phys., 9, 4945-4956, https://doi.org/10.5194/acp-94945-2009, 2009.

Reissell, A. and Arey, J.: Biogenic volatile organic compounds at Azusa and elevated sites during the 1997 Southern California Ozone Study, J. Geophys. Res.-Atmos., 106, 1607-1621, https://doi.org/10.1029/2000jd900517, 2001.

Rhew, R. C., Deventer, M. J., Turnipseed, A. A., Warneke, C., Ortega, J., Shen, S., Martinez, L., Koss, A., Lerner, B. M., Gilman, J. B., Smith, J. N., Guenther, A. B., and de Gouw, J. A.: Ethene, propene, butene and isoprene emissions from a ponderosa pine forest measured by relaxed eddy accumulation, Atmos. Chem. Phys., 17, 13417-13438, https://doi.org/10.5194/acp-17-134172017, 2017.

Rohrer, F., Lu, K. D., Hofzumahaus, A., Bohn, B., Brauers, T., Chang, C. C., Fuchs, H., Haseler, R., Holland, F., Hu, M., Kita, K., Kondo, Y., Li, X., Lou, S. R., Oebel, A., Shao, M., Zeng, L. M., Zhu, T., Zhang, Y. H., and Wahner, A.: Maximum efficiency in the hydroxyl-radical-based self-cleansing of the troposphere, Nat. Geosci., 7, 559-563, https://doi.org/10.1038/ngeo2199, 2014.

Santos, F., Longo, K., Guenther, A., Kim, S., Gu, D., Oram, D., Forster, G., Lee, J., Hopkins, J., Brito, J., and Freitas, S.:
Biomass burning emission disturbances of isoprene oxidation in a tropical forest, Atmos. Chem. Phys., 18, 12715-12734, https://doi.org/10.5194/acp-18-12715-2018, 2018.

Saunders, S. M., Jenkin, M. E., Derwent, R. G., and Pilling, M. J.: Protocol for the development of the Master Chemical Mechanism, MCM v3 (Part A): tropospheric degradation of nonaromatic volatile organic compounds, Atmos. Chem. Phys., 3, 161-180, https://doi.org/10.5194/acp-3-161-2003, 2003.

Seco, R., Peñuelas, J., Filella, I., Llusià, J., Molowny-Horas, R., Schallhart, S., Metzger, A., Müller, M., and Hansel, A.: Contrasting winter and summer VOC mixing ratios at a forest site in the Western Mediterranean Basin: the effect of local biogenic emissions, Atmos. Chem. Phys., 11, 13161-13179, https://doi.org/10.5194/acp-11-13161-2011, 2011.

SFAPRC: Statistics of Forest Resources in China (2009-2013): The 8th national forest inventory. State Forestry Administration, China, China Forestry Publishing House, 2014 (in Chinese).

Sharkey, T. D. and Yeh, S.: Isoprene emission from plants, Annu. Rev. Plant Biol., 52, 407-436, 2003.

Shiu, C. J., Liu, S. C., Chang, C. C., Chen, J. P., Chou, C. C. K., Lin, C. Y., and Young, C. Y.: Photochemical production of ozone and control strategy for Southern Taiwan, Atmos. Environ., 41, 9324-9340, https://doi.org/10.1016/j.atmosenv.2007.09.014, 2007.

Sobanski, N., Tang, M. J., Thieser, J., Schuster, G., Pöhler, D., Fischer, H., Song, W., Sauvage, C., Williams, J., Fachinger, J., Berkes, F., Hoor, P., Platt, U., Lelieveld, J., and Crowley, J. N.: Chemical and meteorological influences on the lifetime of $\mathrm{NO}_{3}$ at a semi-rural mountain site during PARADE, Atmos. Chem. Phys., 16, 4867-4883, https://doi.org/10.5194/acp16-4867-2016, 2016.

Sprengnether, M., Demerjian, K. L., Donahue, N. M., and Anderson, J. G.: Product analysis of the $\mathrm{OH}$ oxidation of isoprene and 1,3-butadiene in the presence of NO, J. Geophys. Res.-Atmos., 107, 4268, https://doi.org/10.1029/2001JD000716, 2002.

Stroud, C. A., Roberts, J. M., Goldan, P. D., Kuster, W. C., Murphy, P. C., Williams, E. J., Hereid, D., Parrish, D., Sueper, D., Trainer, M., Fehsenfeld, F. C., Apel, E. C., Riemer, D., Wert, B., Henry, B., Fried, A., Martinez-Harder, M., Harder, H., Brune, W. H., Li, G., Xie, H., and Young, V. L.: Isoprene and its oxidation products, methacrolein and methylvinyl ketone, at an urban forested site during the 1999 Southern Oxidants Study, J. Geophys. Res.Atmos., 106, 8035-8046, https://doi.org/10.1029/2000jd900628, 2001.

Stutz, J., Alicke, B., Ackermann, R., Geyer, A., White, A. B., and Williams, E. J.: Vertical profiles of $\mathrm{NO}_{3}, \mathrm{~N}_{2} \mathrm{O}_{5}, \mathrm{O}_{3}$, and $\mathrm{NO}_{x}$ in the nocturnal boundary layer: 1 . Observations during the Texas Air Quality Study 2000, J. Geophys. Res., 109, D12306, https://doi.org/10.1029/2003JD004209, 2004.

Su, L., Patton, E. G., Vilà-Guerau de Arellano, J., Guenther, A. B., Kaser, L., Yuan, B., Xiong, F., Shepson, P. B., Zhang, L., Miller, D. O., Brune, W. H., Baumann, K., Edgerton, E., Weinheimer, A., Misztal, P. K., Park, J.-H., Goldstein, A. H., Skog, K. M., Keutsch, F. N., and Mak, J. E.: Understanding isoprene photooxidation using observations and modeling over a subtropical forest in the southeastern US, Atmos. Chem. Phys., 16, 7725-7741, https://doi.org/10.5194/acp-16-7725-2016, 2016.

Tang, J. H., Chan, L. Y., Chang, C. C., Liu, S., and Li, Y. S.: Characteristics and sources of non-methane hydrocar- 
bons in background atmospheres of eastern, southwestern, and southern China, J. Geophys. Res.-Atmos., 114, D03304, https://doi.org/10.1029/2008jd010333, 2009.

Taraborrelli, D., Lawrence, M. G., Crowley, J. N., Dillon, T. J., Gromov, S., Groß, C. B. M., Vereecken, L., and Lelieveld, J.: Hydroxyl radical buffered by isoprene oxidation over tropical forests, Nat. Geosci., 5, 190-193, https://doi.org/10.1038/ngeo1405, 2012.

Vilà-Guerau de Arellano, J., Patton, E. G., Karl, T., van den Dries, K., Barth, M. C., and Orlando, J. J.: The role of boundary layer dynamics on the diurnal evolution of isoprene and the hydroxyl radical over tropical forests, J. Geophys. Res., 116, D07304, https://doi.org/10.1029/2010jd014857, 2011

Wang, H. C., Lu, K. D., Tan, Z. F., Sun, K., Li, X., Hu, M., Shao, M., Zeng, L. M., Zhu, T., and Zhang, Y. H.: Model simulation of $\mathrm{NO}_{3}, \mathrm{~N}_{2} \mathrm{O}_{5}$ and $\mathrm{ClNO}_{2}$ at a rural site in Beijing during CAREBeijing-2006, Atmos. Res., 196, 97-107, https://doi.org/10.1016/j.atmosres.2017.06.013, 2017.

Wang, M., Zeng, L. M., Lu, S. H., Shao, M., Liu, X. L., Yu, X. N., Chen, W. T., Yuan, B., Zhang, Q., Hu, M., and Zhang, Z. Y.: Development and validation of a cryogen-free automatic gas chromatograph system (GC-MS/FID) for online measurements of volatile organic compounds, Anal. Methods, 6, 9424-9434, https://doi.org/10.1039/c4ay01855a, 2014.

Wang, T., Guo, H., Blake, D. R., Kwok, Y. H., Simpson, I. J., and Li, Y. S.: Measurements of trace gases in the inflow of South China Sea background air and outflow of regional pollution at Tai O, Southern China, J. Atmos. Chem., 52, 295-317, https://doi.org/10.1007/s10874-005-2219-x, 2005.

Wang, T., Wei, X. L., Ding, A. J., Poon, C. N., Lam, K. S., Li, Y. S., Chan, L. Y., and Anson, M.: Increasing surface ozone concentrations in the background atmosphere of Southern China, 1994-2007, Atmos. Chem. Phys., 9, 6217-6227, https://doi.org/10.5194/acp-9-6217-2009, 2009.

Wang, T., Xue, L., Brimblecombe, P., Lam, Y. F., Li, L., and Zhang, L.: Ozone pollution in China: A review of concentrations, meteorological influences, chemical precursors, and effects, Sci. Total Environ., 575, 1582-1596, https://doi.org/10.1016/j.scitotenv.2016.10.081, 2017.

Wang, Y., Wang, H., Guo, H., Lyu, X., Cheng, H., Ling, Z., Louie, P. K. K., Simpson, I. J., Meinardi, S., and Blake, D. R.: Longterm $\mathrm{O}_{3}$-precursor relationships in Hong Kong: field observation and model simulation, Atmos. Chem. Phys., 17, 10919-10935, https://doi.org/10.5194/acp-17-10919-2017, 2017.

Wayne, R. P., Barnes, I., Biggs, P., Burrows, J. P., Canosamas, C. E., Hjorth, J., Bras, G. L., Moortgat, G. K., Perner, D., Poulet, G., Restelli, G., and Sidebottom, H.: The Nitrate Radical: Physics, Chemistry and the Atmosphere, Atmos. Environ., 25, 1-203, 1991.

Wolfe, G. M., Kaiser, J., Hanisco, T. F., Keutsch, F. N., de Gouw, J. A., Gilman, J. B., Graus, M., Hatch, C. D., Holloway, J., Horowitz, L. W., Lee, B. H., Lerner, B. M., LopezHilifiker, F., Mao, J., Marvin, M. R., Peischl, J., Pollack, I. B., Roberts, J. M., Ryerson, T. B., Thornton, J. A., Veres, P. R., and Warneke, C.: Formaldehyde production from isoprene oxidation across $\mathrm{NO}_{x}$ regimes, Atmos. Chem. Phys., 16, 2597-2610, https://doi.org/10.5194/acp-16-2597-2016, 2016.

Wu, F., Yu, Y., Sun, J., Zhang, J., Wang, J., Tang, G., and Wang, Y.: Characteristics, source apportionment and reactivity of ambi- ent volatile organic compounds at Dinghu Mountain in Guangdong Province, China, Sci. Total Environ., 548-549, 347-359, https://doi.org/10.1016/j.scitotenv.2015.11.069, 2016.

Wu, M., Wu, D., Fan, Q., Wang, B. M., Li, H. W., and Fan, S. J.: Observational studies of the meteorological characteristics associated with poor air quality over the Pearl River Delta in China, Atmos. Chem. Phys., 13, 10755-10766, https://doi.org/10.5194/acp-13-10755-2013, 2013.

Xiao, R., Takegawa, N., Kondo, Y., Miyazaki, Y., Miyakawa, T., Hu, M., Shao, M., Zeng, L. M., Hofzumahaus, A., Holland, F., Lu, K., Sugimoto, N., Zhao, Y., and Zhang, Y. H.: Formation of submicron sulfate and organic aerosols in the outflow from the urban region of the Pearl River Delta in China, Atmos. Environ., 43, 3754-3763, https://doi.org/10.1016/j.atmosenv.2009.04.028, 2009.

Xu, Z., Wang, T., Xue, L. K., Louie, P. K. K., Luk, C. W. Y., Gao, J., Wang, S. L., Chai, F. H., and Wang, W. X.: Evaluating the uncertainties of thermal catalytic conversion in measuring atmospheric nitrogen dioxide at four differently polluted sites in China, Atmos. Environ., 76, 221-226, https://doi.org/10.1016/j.atmosenv.2012.09.043, 2013.

Xue, L., Gu, R., Wang, T., Wang, X., Saunders, S., Blake, D., Louie, P. K. K., Luk, C. W. Y., Simpson, I., Xu, Z., Wang, Z., Gao, Y., Lee, S., Mellouki, A., and Wang, W.: Oxidative capacity and radical chemistry in the polluted atmosphere of Hong Kong and Pearl River Delta region: analysis of a severe photochemical smog episode, Atmos. Chem. Phys., 16, 9891-9903, https://doi.org/10.5194/acp-16-9891-2016, 2016.

Xue, L. K., Wang, T., Guo, H., Blake, D. R., Tang, J., Zhang, X. C., Saunders, S. M., and Wang, W. X.: Sources and photochemistry of volatile organic compounds in the remote atmosphere of western China: results from the Mt. Waliguan Observatory, Atmos. Chem. Phys., 13, 8551-8567, https://doi.org/10.5194/acp13-8551-2013, 2013.

Xue, L. K., Wang, T., Louie, P. K., Luk, C. W., Blake, D. R., and $\mathrm{Xu}, \mathrm{Z}$.: Increasing external effects negate local efforts to control ozone air pollution: a case study of Hong Kong and implications for other Chinese cities, Environ. Sci. Technol., 48, 1076910775, https://doi.org/10.1021/es503278g, 2014a.

Xue, L. K., Wang, T., Gao, J., Ding, A. J., Zhou, X. H., Blake, D. R., Wang, X. F., Saunders, S. M., Fan, S. J., Zuo, H. C., Zhang, Q. Z., and Wang, W. X.: Ground-level ozone in four Chinese cities: precursors, regional transport and heterogeneous processes, Atmos. Chem. Phys., 14, 13175-13188, https://doi.org/10.5194/acp-1413175-2014, 2014b.

Yang, Y., Shao, M., Keßel, S., Li, Y., Lu, K., Lu, S., Williams, J., Zhang, Y., Zeng, L., Nölscher, A. C., Wu, Y., Wang, X., and Zheng, J.: How the $\mathrm{OH}$ reactivity affects the ozone production efficiency: case studies in Beijing and Heshan, China, Atmos. Chem. Phys., 17, 7127-7142, https://doi.org/10.5194/acp17-7127-2017, 2017.

Zaveri, R. A., Saylor, R. D., Peters, L. K., McNider, R., and Song, A.: A model investigation of summertime diurnal ozone behaviour in rural mountainous locations, Atmos. Environ., 29, 1043-1065, 1995.

Zha, Q.: Measurement of nitrous acid (HONO) and the implications to photochemical pollution, MPhil dissertation, Department of Civil and Environmental Engineering, The Hong Kong Polytechnic University, 2015. 
Zheng, J. Y., Zhong, L. J., Wang, T., Louie, P. K. K., and Li, Z. C.: Ground-level ozone in the Pearl River Delta region: Analysis of data from a recently established regional air quality monitoring network, Atmos. Environ., 44, 814-823, https://doi.org/10.1016/j.atmosenv.2009.11.032, 2010.
Zhu, Y., Yang, L., Kawamura, K., Chen, J., Ono, K., Wang, X., Xue, L., and Wang, W.: Contributions and source identification of biogenic and anthropogenic hydrocarbons to secondary organic aerosols at Mt. Tai in 2014, Environ. Pollut., 220, 863-872, https://doi.org/10.1016/j.envpol.2016.10.070, 2017. 